\title{
Poromicromechanics reveals that physiological bone strains induce osteocyte-stimulating lacunar pressure
}

\author{
Stefan Scheiner $^{1} \cdot$ Peter Pivonka $^{2} \cdot$ Christian Hellmich $^{1}$
}

Received: 18 December 2014 / Accepted: 5 July 2015 / Published online: 30 July 2015

(C) The Author(s) 2015. This article is published with open access at Springerlink.com

\begin{abstract}
Mechanical loads which are macroscopically acting onto bony organs, are known to influence the activities of biological cells located in the pore spaces of bone, in particular so the signaling and production processes mediated by osteocytes. The exact mechanisms by which osteocytes are actually able to "feel" the mechanical loading and changes thereof, has been the subject of numerous studies, and, while several hypotheses have been brought forth over time, this topic has remained a matter of debate. Relaxation times reported in a recent experimental study of Gardinier et al. (Bone 46(4):1075-1081, 2010) strongly suggest that the lacunar pores are likely to experience, during typical physiological load cycles, not only fluid transport, but also undrained conditions. The latter entail the buildup of lacunar pore pressures, which we here quantify by means of a thorough multiscale modeling approach. In particular, the proposed model is based on classical poroelasticity theory, and able to account for multiple pore spaces. First, the model reveals distinct nonlinear dependencies of the resulting lacunar (and vascular) pore pressures on the underlying bone composition, highlighting the importance of a rigorous multiscale approach for appropriate computation of the aforementioned pore pressures. Then, the derived equations are evaluated for macroscopic (uniaxial as well as hydrostatic) mechanical loading of physiological magnitude. The resulting model-predicted pore pressures agree very well
\end{abstract}

Stefan Scheiner

stefan.scheiner@tuwien.ac.at

1 Institute for Mechanics of Materials and Structures, TU Wien-Vienna University of Technology, Karlsplatz 13/202, A-1040 Vienna, Austria

2 St. Vincent's Department of Surgery, The University of Melbourne, Clinical Science Building, 29 Regent Street, VIC 3065, Australia with the pressures that have been revealed, by means of in vitro studies, to be of adequate magnitude for modulating the responses of biological cells, including osteocytes. This underlines that osteocytes may respond to many types of loading stimuli at the same time, in particular so to fluid flow and hydrostatic pressure.

Keywords Poroelasticity - Micromechanics - Osteocytes · Bone remodeling $\cdot$ Mechanosensing $\cdot$ Hydrostatic pressure

\section{Introduction}

Quite recently, Gardinier et al. (2010) presented a brilliant modification of the seminal work of Qin et al. (2002), allowing for the first time ever direct experimental access to the permeability of the lacunar-canalicular system of bone-they reported pressurization and relaxation times of around $8 \mathrm{~s}$, relating to filling or drainage across the osteonal thickness, typically measuring about 65 microns (Gardinier et al. 2010). The underlying pressure intensification and relaxation system is governed by a constant pressure diffusion coefficient $c$ (Zeng et al. 1994; Cowin 1999; Gardinier et al. 2010), being equal to the square of the characteristic length (here the osteonal thickness) over the characteristic relaxation time, $c=l^{2} / T_{\text {relax }}=65^{2} / 8 \approx 530 \mu \mathrm{m}^{2} / \mathrm{s}$. Accordingly, pressure relaxation through fluid flow over the distance between two lacunae, amounting to some 20 microns-see, e.g., Gardinier et al. (2010), Fig. 3b-takes about $T_{\text {relax }}=20^{2} / c \approx 0.8 \mathrm{~s}$. In other words, for characteristic loading times of $1 \mathrm{~s}$ or more, canalicular fluid flow between lacunae is probable to occur, while the fluid is virtually trapped once loading times much below $1 \mathrm{~s}$ are encountered. Interestingly, both time regimes may be encountered under normal physiological loading, as can readily be derived from the wealth of experimental 
data available in the literature: Typical loading rates experienced in bone in vivo are accessible via force or strain measurements, see, e.g., Lanyon et al. (1975) and Bergmann et al. (1993). Magnitude and rate of these physical quantities allow for determination of characteristic loading times defined along the lines of Auriault et al. (2009),

$T_{\text {load }}=\frac{|Q|}{|\dot{Q}|}$

with $Q$ standing for the measured physical quantity, be it strain or force. During a typical load cycle experienced in vivo or subjected to in an in vitro experiment, the value for $T_{\text {load }}$ according to Eq. (1) obviously changes with time: It reaches infinity whenever the measured quantity reaches a maximum or minimum, and minimal characteristic times are encountered at time points in-between, typically close to the time instants at which the measured quantity exhibits maximum rates, see, e.g., Fig. 1a for the resultant force history associated to a human hip joint during walking (Bergmann et al. 1993). The occurring loading times illustrated in Fig. 1b, as derived from the force history of Fig. 1a by means of Eq. (1), may be binned into four time intervals characterizing different orders of magnitudes: load regime I with $T_{\text {load }}<0.1 \mathrm{~s}$; load regime II with $0.1 \mathrm{~s} \leq T_{\text {load }}<1 \mathrm{~s}$; load
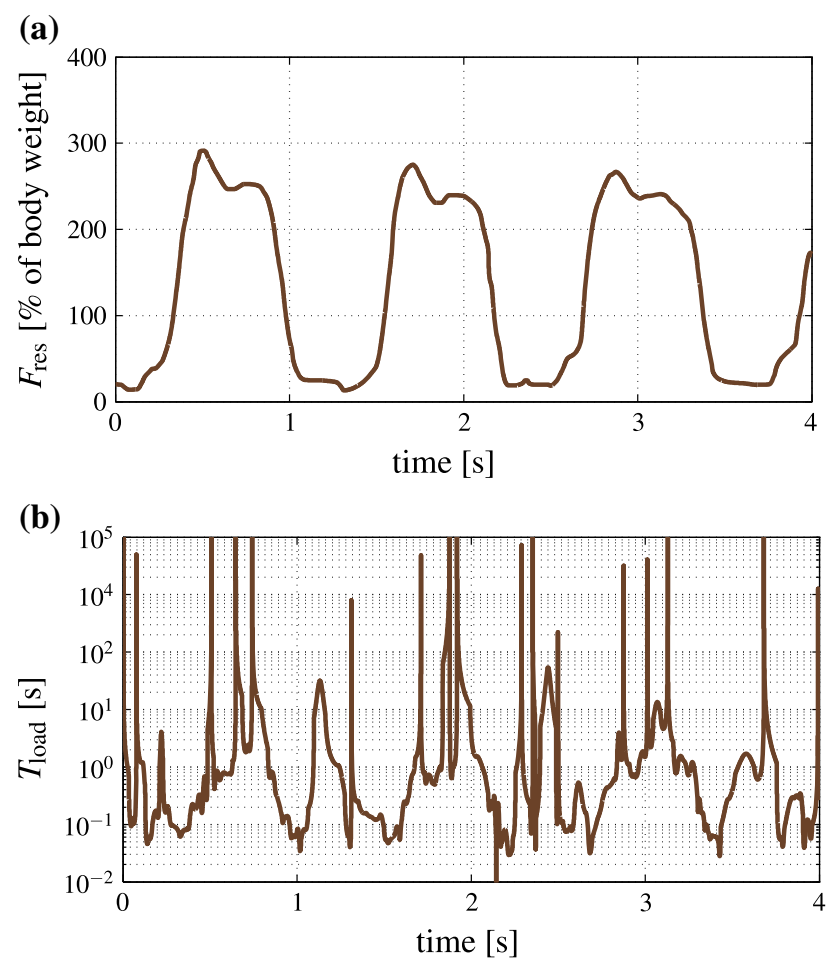

Fig. 1 Bone loading experienced in the hip joint during walking on a treadmill at $2 \mathrm{~km} / \mathrm{h}$ : a resultant force history as recorded by Bergmann et al. (1993), and b corresponding loading times $T_{\text {load }}$ according to Eq. (1) regime III with $1 \mathrm{~s} \leq T_{\text {load }}<10 \mathrm{~s}$; and load regime IV with $T_{\text {load }} \geq 10 \mathrm{~s}$, see Table 1 . It appears that activities like uphill running, jogging, or walking imply a large fraction of characteristic loading times below a tenth of a second; this fraction may amount even up to $74 \%$, according to Mikić and Carter (1995), see Table 1. By contrast, static exercise regimes, such as knee bending (in sports medicine also known as "squats") or the handling with dumbbells entail typically much longer characteristic loading times; e.g., almost $50 \%$ of the slow movement of dumbbells from the lateral position to the front position and back, as recorded by Rohlmann et al. (2014), related to loading times larger than $10 \mathrm{~s}$.

All the loading times of Table 1, which amount to, or even exceed the $8 \mathrm{~s}$-relaxation time suggested by Gardinier et al. (2010) for the osteonal scale, clearly indicate the occurrence of fluid flow through the canaliculi, as has been discussed and reported very extensively in the literature (Turner and Pavalko 1998; Qin et al. 2003; Knothe Tate 2003; Santos et al. 2009; Jacobs et al. 2010). On the other hand, a significant portion of the recorded loading times are well shorter than both the $8 \mathrm{~s}-$ and 0.8 s-relaxation times mentioned previously, so that undrained conditions are expected to occur during physiological loading as well, both at the osteonal and the inter-lacunar scale. Undrained conditions imply pressurization of the lacunar fluid, and this strongly motivates to carefully reconsider hydrostatic pressure as an important stimulus for osteocytes, thus re-energizing a quite old discussion. In fact, the idea of a hydrostatic pressure stimulus is often attributed to Thompson (1936), see, e.g., Bassett (1968). While Thompson's suggestion was mainly founded on intuition and plausibility, in vitro studies repeatedly confirmed that bone cells (not only osteocytes, but also osteoblasts, osteoclasts, and their progenitors) indeed exhibit altered activities when subjected to hydrostatic pressure at frequencies of up to $1 \mathrm{~Hz}$, exhibiting amplitudes of several tens (to hundreds) of kilopascals, see Table 2 for a related literature review. However, while the in vitro stimulation of bone cells by hydrostatic pressure seems to be a generally accepted fact, there seems to be some doubt on whether the hydrostatic pressures identified as mechanical stimuli in vitro are actually occurring in vivo. This doubt is exemplified by a quotation from the famous paper of Duncan and Turner (1995), reading "hydrostatic pressure almost never occurs in mineralized bone". This statement is true and false at the same time, depending on the length scale considered. At the millimeter length scale of a piece of cortical or trabecular bone, it is of course true, since most of the bones are subjected to stress gradients and exhibit one or two dominant loading directions, making the occurrence of hydrostatic pressure (at the millimeter scale) indeed extremely improbable. The setting changes, however, at the tens-of-microns length scale of a single lacunar pore (and of the osteocyte it hosts), where the millimeter-sized gra- 
Table 1 Distribution of characteristic loading times related to in vivo mechanical loading data recorded in humans, for various organs and loading regimes; I: $T_{\text {load }}<0.1 \mathrm{~s}$, II: $0.1 \mathrm{~s} \leq T_{\text {load }}<1 \mathrm{~s}$, IIII $1 \mathrm{~s} \leq T_{\text {load }}<10 \mathrm{~s}$, and IV: $10 \mathrm{~s} \leq T_{\text {load }}$

\begin{tabular}{|c|c|c|c|c|c|c|}
\hline References & $\begin{array}{l}\text { Measured } \\
\text { quantity }\end{array}$ & Loading regime & $\mathrm{I}(\%)$ & II $(\%)$ & III $(\%)$ & $\operatorname{IV}(\%)$ \\
\hline \multirow[t]{3}{*}{ Bergmann et al. (1993) } & \multirow[t]{3}{*}{ Hip joint force } & $\begin{array}{l}\text { Walking on a treadmill at } \\
2 \mathrm{~km} / \mathrm{h}\end{array}$ & 20 & 45 & 25 & 10 \\
\hline & & Jogging on a treadmill at $8 \mathrm{~km} / \mathrm{h}$ & 39 & 51 & 6 & 4 \\
\hline & & Stumbling without falling & 4 & 62 & 28 & 6 \\
\hline \multirow[t]{3}{*}{ Mikić and Carter (1995) } & \multirow{3}{*}{$\begin{array}{l}\text { Anteromedial } \\
\text { tibial strain } \\
\text { energy }\end{array}$} & $\begin{array}{l}\text { Walking on a treadmill at } \\
1.4 \mathrm{~m} / \mathrm{s}\end{array}$ & 56 & 36 & 6 & 2 \\
\hline & & $\begin{array}{l}\text { Walking on the floor with } 71 \mathrm{~kg} \\
\text { additional weight }\end{array}$ & 48 & 48 & 3 & 1 \\
\hline & & $\begin{array}{l}\text { Jogging on a treadmill at } \\
2.2 \mathrm{~m} / \mathrm{s}\end{array}$ & 74 & 22 & 3 & 1 \\
\hline \multirow[t]{3}{*}{ Burr et al. (1996) } & \multirow{3}{*}{$\begin{array}{l}\text { Tibial midshaft } \\
\text { strains }\end{array}$} & Walking on the floor at $5 \mathrm{~km} / \mathrm{h}$ & 35 & 48 & 15 & 2 \\
\hline & & Jogging on the floor at $10 \mathrm{~km} / \mathrm{h}$ & 55 & 33 & 9 & 3 \\
\hline & & Zigzag-running uphill & 58 & 33 & 5 & 4 \\
\hline Nikoyaan et al. (2009) & $\begin{array}{l}\text { Shoulder joint } \\
\text { force }\end{array}$ & Full range of shoulder motions & $\approx 0$ & 30 & 57 & 13 \\
\hline \multirow[t]{3}{*}{ Kutzner et al. (2010) } & \multirow[t]{3}{*}{ Knee joint force } & Knee bending & $\approx 0$ & 17 & 63 & 20 \\
\hline & & Standing up and sitting down & 3 & 35 & 43 & 19 \\
\hline & & Ascending stairs & 12 & 67 & 17 & 4 \\
\hline Rohlmann et al. (2014) & Spinal force & $\begin{array}{l}5 \mathrm{~kg} \text { dumbbells moved from } \\
\text { lateral to front position and } \\
\text { back }\end{array}$ & 0 & 1 & 51 & 48 \\
\hline
\end{tabular}

dients are not "seen" anymore, and which therefore could be well subjected to hydrostatic pressure (at the micron scale).

The latter suggestion of course deserves further scrutiny, and while direct pressure measurements at the micron scale remain out of reach, significant progress in theoretical and computational bone micromechanics over the last 15 years makes it nowadays possible to indeed "downscale" macroscopic strains occurring in vivo, to the fluid pressures arising in the lacunar pore spaces of cortical or trabecular bone tissue, and to check whether the resulting pore pressures agree with those needed to stimulate the cells occurring in bone in vitro. This is exactly the scope of the present paper, the remainder of which is organized as follows:

After a review of the differently sized pore spaces found in bone (see Sect. 2.1), the fundamentals of poromicromechanics are shortly summarized, focussing thereby on the representation of the double-porous system consisting of vascular and lacunar pores with solid bone matrix in-between (see Sects. 2.2 and 2.3); and on the underlying multiscale homogenization scheme which was experimentally validated by tests on bones stemming from the entire vertebrate kingdom, for various physical properties, such as elasticity, wave propagation phenomena, viscoelasticity, and strength (see Sects. 2.4 and 2.5). This scheme then allows for computation of lacunar pressures under different physiologically relevant macroscopic loading scenarios, always involving undrained conditions in the lacunar pores as discussed earlier, but alternatively assuming drained vascular pores [as often expected under normal physiological loading (Smit et al. 2002)], or undrained vascular pores [as expected under traumatic conditions (Hellmich and Ulm 2005a; Bryant 1983)]. The corresponding pressure predictions are then compared to those which have been experimentally shown to stimulate a variety of biological cells in vitro (see Sect. 3.1). After a numerical study concerning age-related changes in bone (see Sect. 3.2), the paper is concluded by an extensive discussion, covering limitations as well as possible future extensions of the poromicromechanics model presented in this paper, as well as its relation to bone mechanobiology and various associated transport processes taking place in the lacunarcanalicular pore channel network (see Sect. 4).

\section{Poromicroelasticity of bone}

The scientific discipline of poromechanics originally emerged from the industrial field of geoengineering (von Terzaghi 1923), where it still drives technological improvements through reliable, often closed form, solutions (Abousleiman et al. 1996), ever extending the seminal work of Biot (1941). Being, however, applicable to any porous medium, poromechanics has gained, during recent decades, 
Table 2 Summary of experimental evidence regarding cell excitation by means of hydrostatic pressure application

\begin{tabular}{|c|c|c|c|c|}
\hline References & Cell type & Pressure magnitude & Pressure frequency & Observed effects \\
\hline Imamura et al. (1990) & $\begin{array}{l}\text { Osteoblast-like } \\
\text { MC3T3-E1 cells }\end{array}$ & $0.5-2 \mathrm{~atm}$ & Static & $\begin{array}{l}\text { Inhibition of osteoblast } \\
\text { differentiation, promotion } \\
\text { of osteoclast production } \\
\text { (“optimum" pressure: } 100 \\
\mathrm{kPa} \text { ), increased PGE } \\
\text { synthesis }\end{array}$ \\
\hline Ozawa et al. (1990) & $\begin{array}{l}\text { Mouse osteoblast-like } \\
\text { MC3T3-E1 cell }\end{array}$ & 1 and $3 \mathrm{~atm}$ & Continuous & $\begin{array}{l}\text { Decreased osteoblast } \\
\text { numbers, increased PGE2 } \\
\text { expression }\end{array}$ \\
\hline Klein-Nulend et al. (1995) & $\begin{array}{l}\text { Osteocytes from chicken } \\
\text { calvariae }\end{array}$ & $13 \mathrm{kPa}$ & 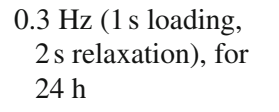 & $\begin{array}{l}\text { Increase in prostaglandin } \\
\text { release (can enhance bone } \\
\text { formation) }\end{array}$ \\
\hline Roelofsen et al. (1995) & $\begin{array}{c}\text { Neonatal mouse } \\
\text { calvarial cells }\end{array}$ & $13 \mathrm{kPa}$ & $0.3 \mathrm{~Hz}$ & $\begin{array}{l}\text { Stimulation of osteoblastic } \\
\text { activity, stimulation of } \\
\text { actin expression, AP } \\
\text { activity }\end{array}$ \\
\hline Brighton et al. (1996) & $\begin{array}{l}\text { Calvarial bone cells } \\
\text { from neonatal rats, } \\
\text { exhibiting an } \\
\text { osteoblast phenotype }\end{array}$ & $17.2-69 \mathrm{kPa}$ & $1 \mathrm{~Hz}$, for 10 cycles & $\begin{array}{l}\text { increased proliferation, } \\
\text { increased cytosolic } \\
\text { calcium concentration }\end{array}$ \\
\hline Vergne et al. (1996) & $\begin{array}{l}\text { ROS 17/2.8 (rat } \\
\text { osteoblast-like cells) }\end{array}$ & $50-90 \mathrm{kPa}$ & $\begin{array}{l}1 \text { and } 0.1 \mathrm{~Hz}, 20 \mathrm{~min} \\
\text { test duration }\end{array}$ & $\begin{array}{l}\text { Increase in cell saturation } \\
\text { density (for a frequency of } \\
1 \mathrm{~Hz} \text { ), decreases alkaline } \\
\text { phosphatase activity }\end{array}$ \\
\hline Rubin et al. (1997) & $\begin{array}{l}\text { Marrow cells from } \\
\text { tibiae and femurs of } \\
\text { C57BL/6 mice }\end{array}$ & $1-2 \mathrm{~atm}$ & Static & $\begin{array}{l}\text { Decreased osteoclast } \\
\text { formation, decrease in } \\
\text { mRNA coding for the } \\
\text { membrane-bound form of } \\
\text { MCSF }\end{array}$ \\
\hline Nagatomi et al. (2001) & $\begin{array}{l}\text { Osteoblasts from the } \\
\text { calvaria of neonatal } \\
\text { rats }\end{array}$ & $10-40 \mathrm{kPa}$ & $\begin{array}{l}0.25 \text { or } 1 \mathrm{~Hz}, 1 \mathrm{~h} \\
\text { daily }\end{array}$ & $\begin{array}{l}\text { Elongated pressure } \\
\text { decreases osteoblast } \\
\text { proliferation, the same } \\
\text { pressure stimulus causes } \\
\text { different effect on } \\
\text { different cells }\end{array}$ \\
\hline Nagatomi et al. (2002) & $\begin{array}{l}\text { Bone marrow cells } \\
\text { (source of osteoclasts) } \\
\text { from rat femurs }\end{array}$ & $10-40 \mathrm{kPa}$ & $\begin{array}{l}1 \mathrm{~Hz} \text { (sinusoidal } \\
\text { wave form), for } 1 \mathrm{~h} \\
\text { per day }\end{array}$ & $\begin{array}{l}\text { Reduced osteoclast } \\
\text { differentiation and } \\
\text { resorption activity, lower } \\
\text { concentration of IL- } 1 \alpha, \\
\text { down-regulation of } \\
\text { mRNA expression for } \\
\text { IL- } 1 \alpha, \text { IL- } 1 \beta \text {, and TNF- } \alpha\end{array}$ \\
\hline Nagatomi et al. (2003) & $\begin{array}{l}\text { Osteoblasts isolated } \\
\text { from rat calvariae }\end{array}$ & $10-40 \mathrm{kPa}$ & $1 \mathrm{~Hz}$, for $1 \mathrm{~h}$ daily & $\begin{array}{l}\text { Increased type-I collagen } \\
\text { mRNA expression, } \\
\text { increased amount of } \\
\text { acid-soluble collagen, } \\
\text { increased calcium } \\
\text { concentration }\end{array}$ \\
\hline Takai et al. (2004) & $\begin{array}{l}\text { Primary osteoblasts } \\
\text { obtained from } \\
\text { trabecular bone cores } \\
\text { taken from the } \\
\text { epiphyses of } \\
\text { metacarpal bones from } \\
\text { 3- to 4-month-old } \\
\text { calves }\end{array}$ & $3 \mathrm{MPa}$ & $\begin{array}{l}0.33 \mathrm{~Hz} \text { (triangle } \\
\text { wave form), for } 1 \\
\text { h/day }\end{array}$ & $\begin{array}{l}\text { Increased osteoblast } \\
\text { function (only when } \\
\text { osteocytes are present), } \\
\text { increased osteocyte } \\
\text { viability }\end{array}$ \\
\hline
\end{tabular}


Table 2 continued

\begin{tabular}{|c|c|c|c|c|}
\hline References & Cell type & Pressure magnitude & Pressure frequency & Observed effects \\
\hline Maul et al. (2007) & $\begin{array}{l}\text { Bone marrow progenitor } \\
\text { cells from rats }\end{array}$ & $10-16 \mathrm{kPa}$ & $1 \mathrm{~Hz}$ & Enhanced proliferation \\
\hline Gardinier et al. (2009) & $\begin{array}{l}\text { MC3T3 osteoblast-like } \\
\text { cells }\end{array}$ & $0-68 \mathrm{kPa}$ & $0.5 \mathrm{~Hz}$ & $\begin{array}{l}\text { Increased anabolic } \\
\text { response, increase in ATP } \\
\text { release, increased COX-2 } \\
\text { levels }\end{array}$ \\
\hline Liu et al. (2009) & $\begin{array}{l}\text { Bone marrow stromal } \\
\text { cells from tibiae and } \\
\text { femurs of rats }\end{array}$ & $10-36 \mathrm{kPa}$ & $\begin{array}{l}0.25 \mathrm{~Hz} \text { (sinusoidal } \\
\text { wave form) }\end{array}$ & $\begin{array}{l}\text { Increase in osteoblast } \\
\text { activity-related } \\
\text { transcription factors }\end{array}$ \\
\hline Liu et al. (2010) & $\begin{array}{l}\text { MLO-Y4 osteocyte-like } \\
\text { cells (i.e., deriving } \\
\text { from cells extracted } \\
\text { from transgenic mice) }\end{array}$ & $68 \mathrm{kPa}$ & $\begin{array}{l}0.5 \mathrm{~Hz} \text { (triangular } \\
\text { wave form), for } 1 \\
\text { or } 2 \mathrm{~h}\end{array}$ & $\begin{array}{l}\text { Decreased osteocyte } \\
\text { apoptosis, increase in } \\
\text { intracellular calcium } \\
\text { (after } 40 \mathrm{~s} \text {, may be related } \\
\text { to osteoblast activity), of } \\
\text { RANKL/OPG ratio (after } \\
2 \mathrm{~h} \text { ), and of COX-2 } \\
\text { mRNA level (after } 1 \mathrm{~h} \text { ) }\end{array}$ \\
\hline Rottmar et al. (2011) & $\begin{array}{l}\text { Human bone- derived } \\
\text { cells, from the hip } \\
\text { marrow }\end{array}$ & $1-11 \mathrm{kPa}$ & $\begin{array}{l}30 \text { min stimulation, } \\
7 \mathrm{~h}, 30 \text { min break }\end{array}$ & $\begin{array}{l}\text { Increased osteogenic } \\
\text { differentiation and } \\
\text { proliferation }\end{array}$ \\
\hline Henstock et al. (2013) & $\begin{array}{l}\text { Cells contained in whole } \\
\text { femurs of chick } \\
\text { foetuses }\end{array}$ & $0-279 \mathrm{kPa}$ & $0.0001-2 \mathrm{~Hz}$ & $\begin{array}{l}\text { Increased volume of } \\
\text { diaphysial collar }\end{array}$ \\
\hline
\end{tabular}

increasing popularity in the biological field, with applications concerning cartilage (Huyghe et al. 2007; Hoang and Abousleiman 2009), brain (Mehrabian and Abousleiman 2011), wood (Bader et al. 2011), or bone (Cowin 1999). Concerning the latter, the theory of poromicromechanics (Dormieux et al. 2006), where not only porosities, but also additional microstructural features are explicitly considered for determining the mechanical interactions between pore pressures and stresses acting on porous material volumes, has been particularly successfully applied to bone (Hellmich and Ulm 2005a,b; Morin and Hellmich 2014), and in this context, has allowed for explaining various experimentally observed pore pressure buildup phenomena (Bryant 1983, 1988; McCarthy et al. 1990; Hosokawa and Otani 1997; Lee et al. 2003). Corresponding experimentally validated mathematical models are employed hereafter, in order to determine the lacunar and vascular pore pressures arising from physiological strains, preceded by a short review on the pore spaces found in bone, as described next.

\subsection{Pore spaces in bone}

The largest pores found in bone host blood vessels and are therefore often called vascular pores. In cortical bone (forming shell-type structures at the surface of whole bony organs), the vascular pores form a branching structure (Cooper et al. 2003), with the main branches (normally following the main anatomical directions of the organ) often being called Haver- sian canals, while the sideways to smaller branches are sometimes called Volkmann canals. Over the lifespan of an individual, the vascular porosity typically increases, from a few percent in young adults, up to $35 \%$ and more at age 90 (Cooper et al. 2007), see Fig. 2a, b. Trabecular bone, surrounded by a cortical shell, can be found at the ends of long bones, proximal to joints, resulting from a perforation process of the cartilage originally laid down during the development of the biological individual (Buckwalter et al. 1995a, b; Byers et al. 2000), with vascular porosities (then also called inter-trabecular porosities) ranging from typically 50-90\% (Padilla et al. 2008; Boutroy et al. 2005, 2011), and also shows a great spatial variability within one and the same organ, see Fig. 2a, e. The interpenetration of vascular pores in trabecular bone results in the appearance of the extravascular bone matrix in-between, as struts or plates, which are called trabeculae. With aging, the latter undergo considerable thinning and may even be lost (Thomsen et al. 2002; Chen et al. 2010).

Within the extravascular bone matrix, another class of pores can be found, with characteristic sizes of ten micrometers, hosting the probably mechanosensitive osteocytes. The corresponding porosity can be straightforwardly determined from sufficiently high-resolution light or transmission/scanning electron micrographs (Buckwalter et al. 1995a; Tai et al. 2008), see Fig. 2c, d, f, and g; it amounts to about $10 \%$ (of the space without the vascular pores). With aging, gradual apoptosis of the osteocytes is observed (Busse 
(a) radiograph of a human femur (as exemplary bone organ)

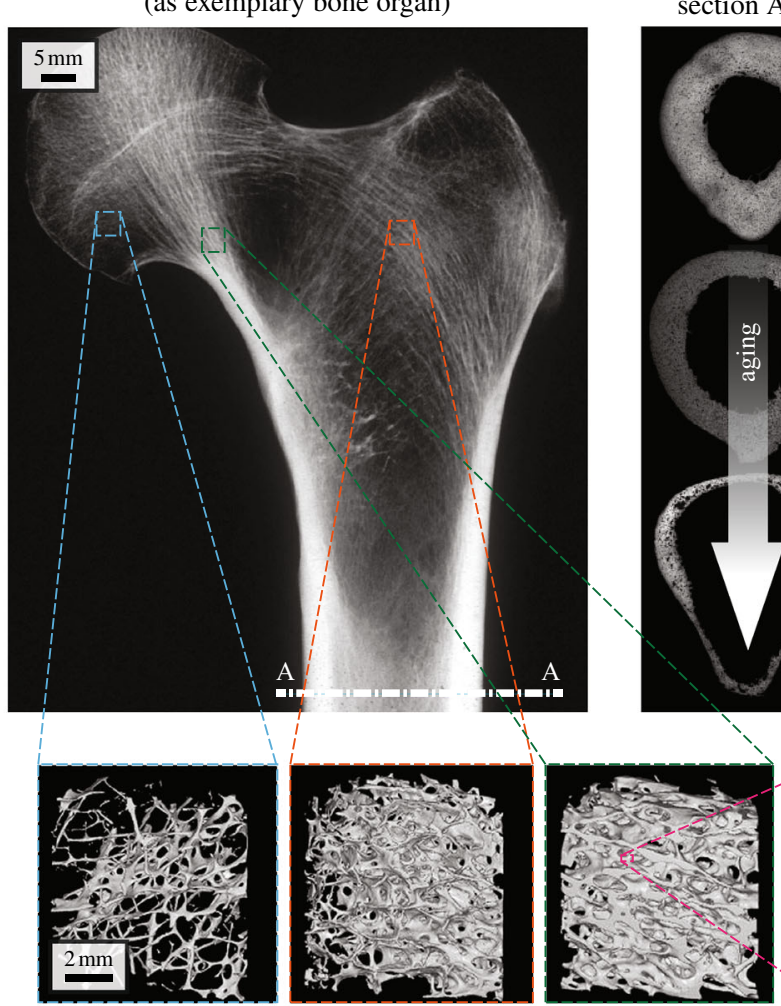

(e) CT-based reconstructions of trabecular bone (b) cross

section A-A (g) SEM image of an osteocyte (c) light micrograph of cortical bone

(d) SEM image of cortical bone
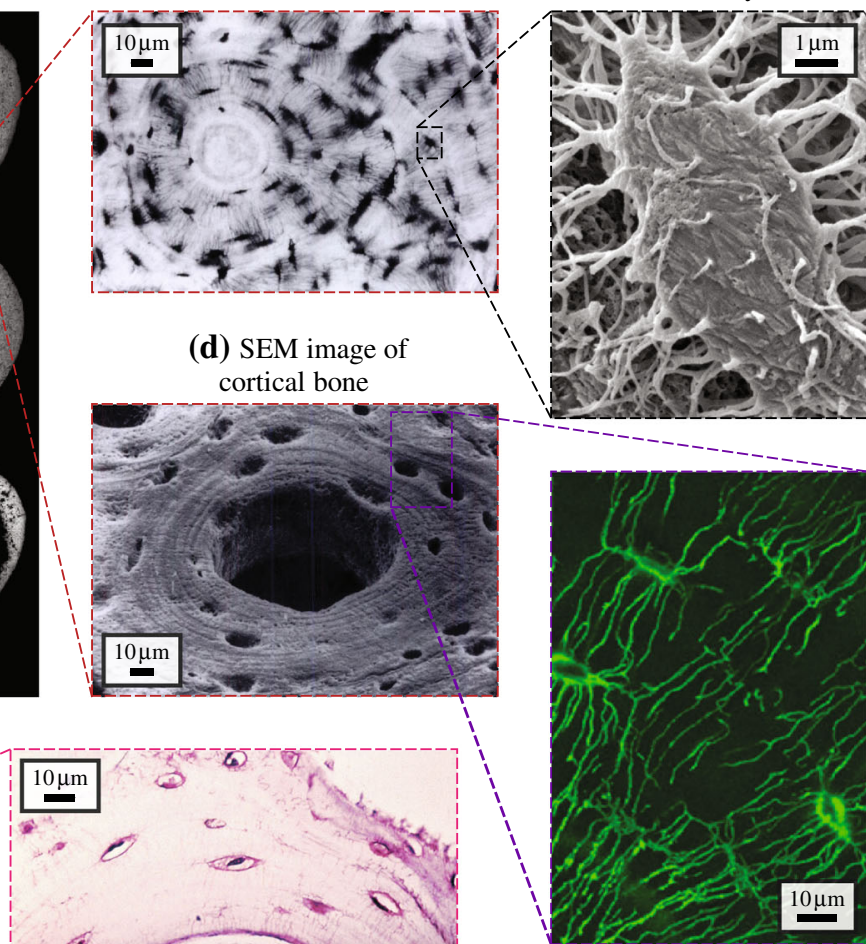

(h) LSCM image of the lacunae-canaliculi system (f) photomicrograph of single trabecula
Fig. 2 Hierarchical organization of bone relevant for bone remodeling-modulating pore pressures, presented by the example of the human femur: a X-ray image of the proximal part of a human femur, reproduced from Sinclair et al. (2013), with permission from Elsevier B.V.; b midshaft cross section A-A, illustrated through corresponding microradiographs of femur cross sections, by courtesy of John G. Clement and David Thomas (taken from the Melbourne Femur Collection), shows deteriorating integrity with increasing age; cortical bone microstructure and its main constituents acquired by means of $\mathbf{c}$ light microscopy, reprinted from Buckwalter and Cooper (1987), with permission from the American Academy of Orthopaedic Surgeons (AAOS), or d scanning electron microscopy (SEM), reprinted from Kessel and Kardon (1979), by courtesy of Randy H. Kardon; e shows

et al.2010), allowing for mineralization of the lacunar spaces; thereby reducing the lacunar porosity.

The lacunae are connected by much smaller channels called canaliculi, which host the osteocyte processes connecting the osteocytes to a network similar to those made up by neurons. These channels have a characteristic diameter of a few $100 \mathrm{~nm}$, typically around $500 \mathrm{~nm}$ (Reilly et al. 2001; Sharma et al. 2012), see Fig. 2h. Since these canalicular pores are much smaller than the lacunar pores, we regard them throughout this paper as a porosity which is of course physically linked to, but at the same time "length-scale-separated" from the lacunar pores. Namely, length-scale separation is one of the most fundamental and governing principles in the very old and therefore highly mature scientific field of computed tomography (CT) images of trabecular bone acquired at different locations showing different porosities, reproduced from Padilla et al. (2008), with permission from Elsevier B.V.; f a photomicrograph of a single trabecula shows the composition of trabecular bone, reproduced from Sinclair et al. (2013), with permission from Elsevier B.V.; g SEM allows to visualize the osteocytes residing in the lacunar pores detectable in cortical bone and trabecular bone, reprinted from Pajevic (2009), by permission from Macmillan Publishers Ltd. on behalf of Cancer Research UK: IBMS BoneKey, (C) 2009; h laser scanning confocal microscopy (LSCM) shows the canaliculi connecting the lacunae and the therein residing osteocytes, forming a dense network embedded in the extracellular bone matrix, reproduced from Ebacher et al. (2012), with permission from Elsevier B.V.

continuum mechanics (Salençon 2001), and its subfields micromechanics (Zaoui 2002) and poromechanics (Coussy 2004; Dormieux et al. 2006), which will be used hereafter to elucidate the mechanical functioning of the different pore spaces found in bone material. Given our focus on the osteocytes and their mechanical environment, all pore spaces smaller than the lacunar pore space, such as the canalicular pore space at the 100 nanometers scale, but also the inter-crystalline and inter-molecular pore spaces at the ten nanometers and the single nanometer scales (Hellmich et al. 2009) will not be explicitly introduced here, but they are considered as an integral part of what we will call in the following "extralacunar bone matrix," i.e., extracellular bone matrix plus canaliculi. 


\subsection{Separation of scales-representative volume elements}

In the following, the mechanical impact of the aforementioned pore spaces is studied within the framework of continuum micromechanics (Hill 1963, 1965; Suquet 1997; Zaoui 1997, 2002; Dormieux et al. 2006), where a material is understood as a macrohomogeneous, but microheterogeneous body filling a representative volume element (RVE) with characteristic length $\ell_{\mathrm{RVE}}$, fulfilling the following separation-of-scales conditions: (i) $\ell_{\mathrm{RVE}} \gg d_{\mathrm{RVE}}, d_{\mathrm{RVE}}$ representing the characteristic length of inhomogeneities within the RVE, and (ii) $\ell_{\mathrm{RVE}} \ll\{\mathscr{L}, \mathscr{P}\}, \mathscr{L}$ representing the characteristic length of the geometry and $\mathscr{P}$ representing the characteristic length of the loading of a structure built up by the material defined on the RVE.

In general, the microstructure within one RVE is so complicated that it cannot be described in complete detail. Therefore, quasi-homogeneous subdomains with known physical properties are reasonably chosen. They are called material phases, typically comprising solid and pore phases. The homogenized (upscaled) poroelastic behavior of the material on the observation scale of the RVE, i.e., the relation between homogeneous deformations acting on the boundary of the RVE, the pressures acting inside the pores, and the resulting macroscopic (average) stresses, can then be estimated from the elastic behavior of the material phases, their volume fractions within the RVE, their characteristic shapes, and their interactions. If a single phase exhibits a heterogeneous microstructure itself, its mechanical behavior can be estimated by introduction of an RVE within this phase, with dimensions $\ell_{\mathrm{RVE}, 2} \leq d_{\mathrm{RVE}}$, comprising again smaller phases with characteristic length $d_{\mathrm{RVE}, 2} \ll \ell_{\mathrm{RVE}, 2}$, and so on. This leads to a multistep homogenization scheme.

In the case of bone, we adopt a homogenization scheme which has been extensively validated against experimental data across a multitude of bone samples harvested from different anatomical locations of different species of different ages and various physical quantities such as elasticity (Hellmich et al. 2004; Fritsch and Hellmich 2007), poroelasticity (Hellmich and Ulm 2005a,b; Morin and Hellmich 2014), viscoelastcity (Eberhardsteiner et al. 2014), and elastoplasticity (strength) (Fritsch et al. 2009). In the course of this adoption, we start with zooming out of a bony organ with a characteristic length of several $\mathrm{mm}$ to $\mathrm{cm}$, $\mathscr{L}_{\text {bone }}=5 \ldots 10 \times 10^{-3} \mathrm{~m}$, an RVE of (cortical or trabecular) bone, see Fig. 3, which in the case of cortical bone exhibits a typical length of $\ell_{\text {macro }} \approx 1 . . .5 \times 10^{-3} \mathrm{~m}$ (Lees et al. 1979; Padilla et al. 2008), and being somewhat larger in the case of trabecular bone. Within this RVE, we distinguish the phases "vascular pores," exhibiting a characteristic size of $d_{\text {vas }}=50 \ldots 80 \times 10^{-6} \mathrm{~m}$ and cylindrical shape, and "extravascular bone matrix," whereby the former are embed-

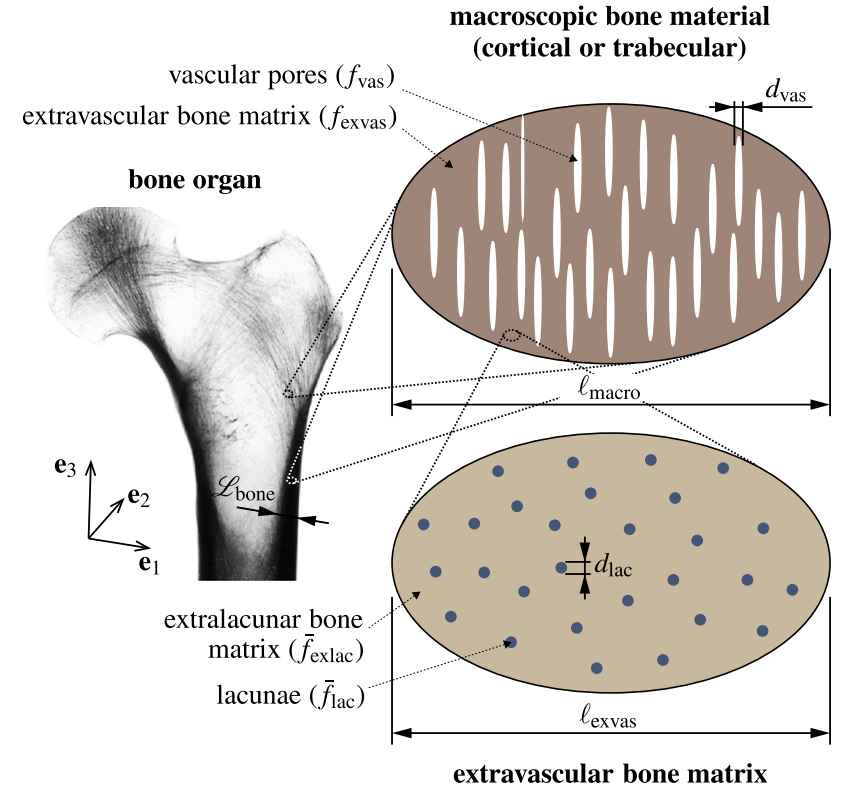

Fig. 3 Micromechanical representation of cortical bone, based on which the poromicromechanical model is developed: Cortical bone microstructure is composed of extravascular bone matrix, with volume fraction $f_{\text {exvas }}$, and vascular pore space, with volume fraction $f_{\text {vas }}$, $f_{\text {exvas }}+f_{\text {vas }}=1, \mathscr{L}_{\text {bone }} \gg \ell_{\text {macro }} \gg d_{\text {vas }}$, whereas extravascular bone matrix is composed of extracellular bone matrix, with volume fraction $\bar{f}_{\text {exlac }}$, and lacunar pores, with volume fraction $\bar{f}_{\text {lac }}, \bar{f}_{\text {exlac }}+\bar{f}_{\text {lac }}=1$, $\ell_{\text {exvas }} \gg d_{\text {lac }}$; the X-ray image of the bone organ was reproduced from Sinclair et al. (2013), with permission of Elsevier B.V.

ded into the latter (Hellmich et al. 2004, 2008; Yosibash et al. 2008; Fritsch et al. 2009; Grimal et al. 2011; Colloca et al. 2014), see Fig. 3. When zooming into a piece of the extravascular bone matrix, it appears as a porous material itself, represented by means of an RVE with a characteristic length of $\ell_{\text {exvas }} \approx 100 \ldots 200 \times 10^{-6} \mathrm{~m}$, being composed of the phases "extralacunar bone matrix" (i.e., extracellular bone matrix plus the therein embedded, comparatively tiny canalicular channels) and "lacunar pores" with characteristic size $d_{\text {lac }} \approx 10 \times 10^{-6} \mathrm{~m}$ (Buckwalter et al. 1995a; Martin et al. 1998), approximated by spherical inclusions (Fritsch and Hellmich 2007; Hellmich et al. 2009; Morin and Hellmich 2014). We note in passing that $d_{\mathrm{RVE}}$ and $\ell_{\mathrm{RVE}}$ are always separated by more than a factor of three, which already allows homogenization results with a low error, of not more than around 3\% (Drugan and Willis 1996).

\subsection{Micro-macro relations in the double-porous medium}

In the framework of linearized (small) strains (standardly used in the mechanical study of mineralized tissues) and elastic behavior of the solid phases of the RVEs depicted in Fig. 3, the "macroscopic" stresses $\boldsymbol{\Sigma}$ related to the macroscopic (cortical or trabecular) RVE (i.e., the spatial average 
of microstresses within this RVE) are linearly related to the "macroscopic" strains E imposed as displacements at the boundary of this RVE, and to the pore pressures $p_{\text {lac }}$ and $p_{\text {vas }}$ acting inside the vascular and lacunar pores, respectively,

$\boldsymbol{\Sigma}=\mathbb{C}_{\text {macro }}: \mathbf{E}-\mathbf{b}_{\text {macro }}^{\text {lac }} p_{\text {lac }}-\mathbf{b}_{\text {macro }}^{\text {vas }} p_{\text {vas }}$,

as has been derived in theoretical detail in Dormieux et al. (2006), Hellmich et al. (2009) and Pichler and Hellmich (2010). This multilinearity is expressed by the "drained" cortical stiffness tensor $\mathbb{C}_{\text {macro }}$ (related to drained lacunar and vascular pores, meaning that the pore pressures are governed by effects from outside the RVE, and comprising particularly the special case of "zero pressures"), and by the pore space-specific Biot tensors $\mathbf{b}_{\text {macro }}^{\text {vas }}$ and $\mathbf{b}_{\text {macro }}^{\text {lac }}$, which quantify the macroscopic stresses $\boldsymbol{\Sigma}$ arising in an undeformed cortical RVE, from pressures acting in the two considered pore spaces. Mathematical details on how the second-order Biot tensors are derived from the micromechanical representation depicted in Fig. 3, are given in the Appendix of this paper.

The macroscopic strains and the pore pressures also lead to changes in the lacunar and vascular porosities, again in a multilinear way,

$f_{\text {lac }}-f_{\text {lac }, 0}=\mathbf{b}_{\text {macro }}^{\text {lac }}: \mathbf{E}+\frac{p_{\text {lac }}}{N_{\text {macro }}^{\text {lac,lac }}}+\frac{p_{\text {vas }}}{N_{\text {macro }}^{\text {lac,vas }}}$

and

$f_{\text {vas }}-f_{\text {vas }, 0}=\mathbf{b}_{\text {macro }}^{\text {vas }}: \mathbf{E}+\frac{p_{\text {lac }}}{N_{\text {macro }}^{\text {vas,lac }}}+\frac{p_{\text {vas }}}{N_{\text {macro }}^{\text {vas,vas }}}$,

where $f_{\text {lac }, 0}$ and $f_{\text {vas, } 0}$ are the initial volume fractions of lacunar and vascular pore spaces (quantified on the macroscopic observation scale), before the RVE of macroscopic (cortical or trabecular) bone is subjected to mechanical loading. Furthermore, $N_{\text {macro }}^{j, j}$ and $N_{\text {macro }}^{j, k}=N_{\text {macro }}^{k, j}$ are the so-called Biot moduli, whose nomenclature is built as follows: Biot modulus $N_{r}^{j, k}$ considers the effect of the pressure in pore space $k$ on the porosity change of pore space $j$, whereby both pore spaces are measured in RVE $r$. We note that the theoretical derivation of Eqs. (3) and (4) is described in greater detail elsewhere (Dormieux et al. 2006; Hellmich et al. 2009; Pichler and Hellmich 2010), and that the Biot moduli are functions of the Biot tensors and of the extralacunar stiffness tensor, as given in more detail in the Appendix of this paper.

\subsection{Sealing of pore spaces I-undrained lacunar pores}

So far, the pore pressures $p_{\text {lac }}$ and $p_{\text {vas }}$ were considered as independent loading variables, governed by the fluid flow conditions met in the double-porous medium. We will now investigate specific cases of these fluid flow conditions. The first case relates to the situation where the macroscopic strains $\mathbf{E}$ (and the corresponding strains acting on the lacunar pores) are built up so quickly that the pore fluid cannot leave any more the lacunar pore space, and that it is therefore "trapped" therein, see the first paragraph of Sect. 1, Table 1, and Fig. 1 for the corresponding physiological conditions. Under such conditions, the lacunar pore deformation is solely governed by the deformation of the lacunar fluid (also comprising the osteocyte) itself, see Hellmich and Ulm (2005a), Hellmich et al. (2009) and Coussy (2004) for further theoretical details,

$\frac{f_{\text {lac }}-f_{\text {lac }, 0}}{f_{\text {lac }, 0}}=-\frac{p_{\text {lac }}}{k_{\text {lac }}}$

where $k_{\text {lac }}$ denotes the bulk modulus of the fluid contained in the lacunar pores, which is standardly approximated by that of water, $k_{\text {lac }}=2.3 \mathrm{GPa}$ (Murdock 1996). At the same time, we consider the case where the aforementioned loading is still slow enough so as to allow the vascular fluid to equilibrate with the (comparatively low) pressure stemming from blood circulation, usually ranging between 10 and $30 \mathrm{mmHg}$ (i.e., 1.33-4 kPa) (Brookes and Revell 1998; Cameron et al. 1999), which we approximate as $p_{\text {vas }} \approx 0$. Insertion of Eq. (5) into Eq. (3) then leads to the following result:

$p_{\text {lac }}=-M_{\text {macro }}^{\text {lac }} \mathbf{b}_{\text {macro }}^{\text {lac }}: \mathbf{E}$,

with the modulus-type quantity $M_{\text {macro }}^{\text {lac }}$ defined standardly as (Coussy 2004; Hellmich et al. 2009)

$\frac{1}{M_{\text {macro }}^{\text {lac }}}=\frac{f_{\text {lac }, 0}}{k_{\text {lac }}}+\frac{1}{N_{\text {macro }}^{\text {lac,lac }}}$.

Insertion of Eq. (6) and $p_{\text {vas }}=0$ into Eq. (2) yields a stressstrain relation of the format

$\boldsymbol{\Sigma}=\mathbb{C}_{\text {macro }}^{\text {lac-u }}: \mathbf{E}$,

with the stiffness tensor $\mathbb{C}_{\text {macro }}^{\text {lac-u }}$ referring to undrained lacunar pores and drained vascular pores,

$\mathbb{C}_{\text {macro }}^{\text {lac-u }}=\mathbb{C}_{\text {macro }}+M_{\text {macro }}^{\text {lac }} \mathbf{b}_{\text {macro }}^{\text {lac }} \otimes \mathbf{b}_{\text {macro }}^{\text {lac }}$

Insertion of Eq. (8) into Eq. (6) then gives

$p_{\text {lac }}=-\left(\mathbf{B}_{\text {macro }}^{\text {lac }}\right)_{\text {lac-u }}: \Sigma$,

with the second-order Skempton tensor $\left(\mathbf{B}_{\text {macro }}^{\text {lac }}\right)_{\text {lac-u }}$ linearly relating macroscopic stresses to the lacunar pore pressure, reading as

$\left(\mathbf{B}_{\text {macro }}^{\text {lac }}\right)_{\text {lac-u }}=M_{\text {macro }}^{\text {lac }} \mathbf{b}_{\text {macro }}^{\text {lac }}:\left(\mathbb{C}_{\text {macro }}^{\text {lac-u }}\right)^{-1}$ 


\subsection{Sealing of pore spaces II-undrained lacunar and vascular pores}

Now we consider the case where also the vascular fluid is "trapped" in its pore space, due to sufficiently high loading rates, of typical characteristic times in the millisecond regime (Bryant 1983; Hellmich and Ulm 2005a). Then, also the vascular porosity changes are driven solely by the compression of the vascular fluid,

$$
\frac{f_{\mathrm{vas}}-f_{\mathrm{vas}, 0}}{f_{\mathrm{vas}, 0}}=-\frac{p_{\mathrm{vas}}}{k_{\mathrm{vas}}},
$$

where we approximate also the vascular bulk modulus by that of water, $k_{\text {vas }}=2.3 \mathrm{GPa}$ (Murdock 1996). Insertion of Eqs. (5) and (12) into Eqs. (3) and (4) yields a linear system of equations for the two unknowns $p_{\text {lac }}$ and $p_{\text {vas }}$, with the solutions

$$
\begin{aligned}
p_{\text {lac }}= & -\frac{M_{\text {macro }}^{\text {lac }} N_{\text {macro }}^{\text {lac,vas }}}{\left(N_{\text {macro }}^{\text {lac, }}\right)^{2}-M_{\text {macro }}^{\text {lac }} M_{\text {macro }}^{\text {vas }}} \\
& \times\left(\mathbf{b}_{\text {macro }}^{\text {vas }} M_{\text {macro }}^{\text {vas }}+\mathbf{b}_{\text {macro }}^{\text {lac }} N_{\text {macro }}^{\text {lac,vas }}\right): \mathbf{E}
\end{aligned}
$$

and

$$
\begin{aligned}
p_{\text {vas }}= & -\frac{M_{\text {macro }}^{\text {vas }} N_{\text {macro }}^{\text {lac, vas }}}{\left(N_{\text {macro }}^{\text {lac,vas }}\right)^{2}-M_{\text {macro }}^{\text {lac }} M_{\text {macro }}^{\text {vas }}} \\
& \times\left(\mathbf{b}_{\text {macro }}^{\text {lac }} M_{\text {macro }}^{\text {lac }}+\mathbf{b}_{\text {macro }}^{\text {vas }} N_{\text {macro }}^{\text {lac,vas }}\right): \mathbf{E},
\end{aligned}
$$

whereby the modulus-type quantity $M_{\text {macro }}^{\text {vas }}$ again follows the standard definition (Coussy 2004)

$\frac{1}{M_{\text {macro }}^{\text {vas }}}=\frac{f_{\text {vas }, 0}}{k_{\text {vas }}}+\frac{1}{N_{\text {macro }}^{\text {vas, vas }}}$.

Insertion of Eqs. (13) and (14) into Eq. (2) yields a stressstrain relation in the format

$\Sigma=\mathbb{C}_{\text {macro }}^{\text {lac,vas-u }}: \mathbf{E}$,

with the stiffness tensor $\mathbb{C}_{\text {macro }}^{\text {lac,us }}$ referring to undrained lacunar and vascular pores,

$$
\begin{aligned}
\mathbb{C}_{\text {macro }}^{\text {lac,vas-u }}= & \mathbb{C}_{\text {macro }}+\mathbf{b}_{\text {macro }}^{\text {lac }} \otimes\left[\frac{M_{\text {macro }}^{\text {lac }} N_{\text {macro }}^{\text {lac,vas }}}{\left(N_{\text {macro }}^{\text {lac,vas }}\right)^{2}-M_{\text {macro }}^{\text {lac }} M_{\text {macro }}^{\text {vas }}}\right. \\
& \left.\times\left(\mathbf{b}_{\text {macro }}^{\text {vas }} M_{\text {macro }}^{\text {vas }}+\mathbf{b}_{\text {macro }}^{\text {lac }} N_{\text {macro }}^{\text {lac, vas }}\right)\right] \\
& +\mathbf{b}_{\text {macro }}^{\text {vas }} \otimes\left[\frac{M_{\text {macro }}^{\text {vas }} N_{\text {macro }}^{\text {lac,vas }}}{\left(N_{\text {macro }}^{\text {lac, vas }}\right)^{2}-M_{\text {macro }}^{\text {lac }} M_{\text {macro }}^{\text {vas }}}\right. \\
& \left.\times\left(\mathbf{b}_{\text {macro }}^{\text {lac }} M_{\text {macro }}^{\text {lac }}+\mathbf{b}_{\text {macro }}^{\text {vas }} N_{\text {macro }}^{\text {lac, vas }}\right)\right]
\end{aligned}
$$

Insertion of Eq. (17) into Eqs. (13) and (14) then yields $p_{\text {lac }}=-\left(\mathbf{B}_{\text {macro }}^{\text {lac }}\right)_{\text {lac,vas-u }}: \boldsymbol{\Sigma}$,

and

$p_{\text {vas }}=-\left(\mathbf{B}_{\text {macro }}^{\text {vas }}\right)_{\text {lac,vas-u }}: \Sigma$,

with the second-order Skempton tensors $\left(\mathbf{B}_{\text {macro }}^{\text {lac }}\right)_{\text {lac,vas-u }}$ and $\left(\mathbf{B}_{\text {macro }}^{\text {vas }}\right)_{\text {lac,vas-u }}$ reading as

$$
\begin{aligned}
\left(\mathbf{B}_{\text {macro }}^{\text {lac }}\right)_{\text {lac,vas-u }}= & \frac{M_{\text {macro }}^{\text {lac }} N_{\text {macro }}^{\text {lac, }}}{\left(N_{\text {macro }}^{\text {lac, vas }}\right)^{2}-M_{\text {macro }}^{\text {lac }} M_{\text {macro }}^{\text {vas }}} \\
& \times\left(\mathbf{b}_{\text {macro }}^{\text {vas }} M_{\text {macro }}^{\text {vas }}+\mathbf{b}_{\text {macro }}^{\text {lac }} N_{\text {macro }}^{\text {lac,vas }}\right) \\
& :\left(\mathbb{C}_{\text {macro }}^{\text {lac,vas-u }}\right)^{-1}
\end{aligned}
$$

and

$$
\begin{aligned}
\left(\mathbf{B}_{\text {macro }}^{\text {vas }}\right)_{\text {lac,vas-u }}= & \frac{M_{\text {macro }}^{\text {vas }} N_{\text {macro }}^{\text {lac,vas }}}{\left(N_{\text {macro }}^{\text {lac,vas }}\right)^{2}-M_{\text {macro }}^{\text {lac }} M_{\text {macro }}^{\text {vas }}} \\
& \times\left(\mathbf{b}_{\text {macro }}^{\text {lac }} M_{\text {macro }}^{\text {lac }}+\mathbf{b}_{\text {macro }}^{\text {vas }} N_{\text {macro }}^{\text {lac,vas }}\right) \\
& :\left(\mathbb{C}_{\text {macro }}^{\text {lac,vas-u }}\right)^{-1} .
\end{aligned}
$$

\section{Results}

\subsection{Pore pressure built up by macroscopic stress and strain states}

Evaluation of Eqs. (2)-(21), together with Eqs.(23)-(38), reveals that the Skempton tensors given by Eqs. (11), (20), and (21) are of diagonal format. That is, in a base frame $\mathbf{e}_{1}, \mathbf{e}_{2}$, and $\mathbf{e}_{3}$ coinciding with the anatomical and pore directions, see Fig. 3, all components $B_{i j}$ with mixed indices, $i \neq j$ vanish, and only the "normal" components $B_{11}, B_{22}$, and $B_{33}$ remain. Hence, the pressure buildup can be given explicitly as

$p=B_{11} \Sigma_{11}+B_{22} \Sigma_{22}+B_{33} \Sigma_{33}$

We directly observe that macroscopic shear loading in the anatomical directions does not induce any pressure buildup. However, this does not mean that macroscopic shearing per se never builds up pore pressure: Whenever the orientation of the shear stress vectors would deviate from the anatomical directions, then they would induce corresponding normal stress tensor components with respect to the anatomical directions, and this would of course evoke pore pressures. What can be also seen from Eq. (22) is that the effect of macroscopic normal stresses in the anatomical directions, on the pore pressure buildup is (anatomical) direction-dependent. This is further quantified in Fig. 4. The lacunar and vascular pressure buildup is lower in axial than in 
(a) $p_{\text {lac }}$ for $\Sigma=\mathrm{e}_{1} \otimes \mathrm{e}_{1}$ or $\Sigma=\mathrm{e}_{2} \otimes \mathrm{e}_{2}$, and drained vascular pores

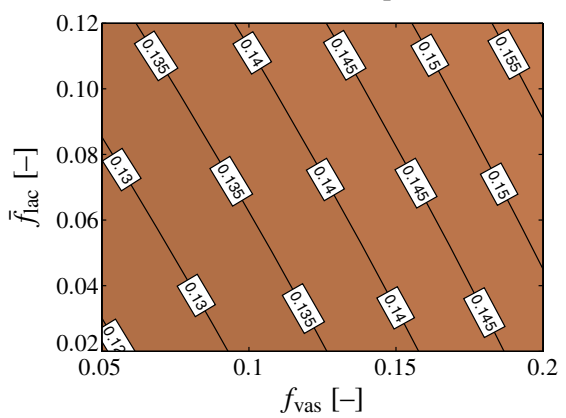

(d) $p_{\text {lac }}$ for $\Sigma=\mathrm{e}_{3} \otimes \mathrm{e}_{3}$ or, and undrained vascular pores

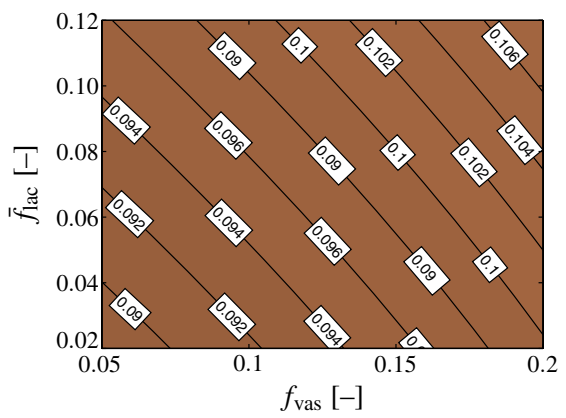

(b) $p_{\text {lac }}$ for $\Sigma=\mathrm{e}_{3} \otimes \mathrm{e}_{3}$, and drained vascular pores

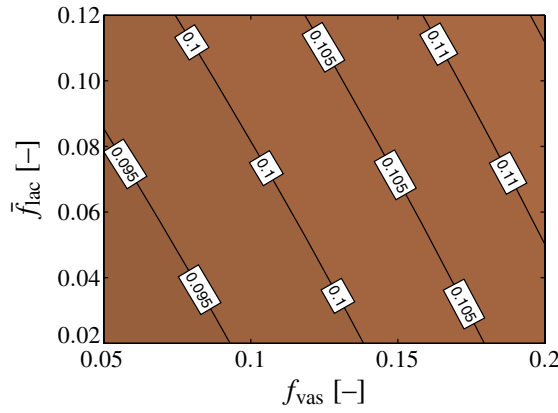

(e) $p_{\text {vas }}$ for $\Sigma=\mathrm{e}_{1} \otimes \mathrm{e}_{1}$ or $\Sigma=\mathrm{e}_{2} \otimes \mathrm{e}_{2}$, and undrained vascular pores

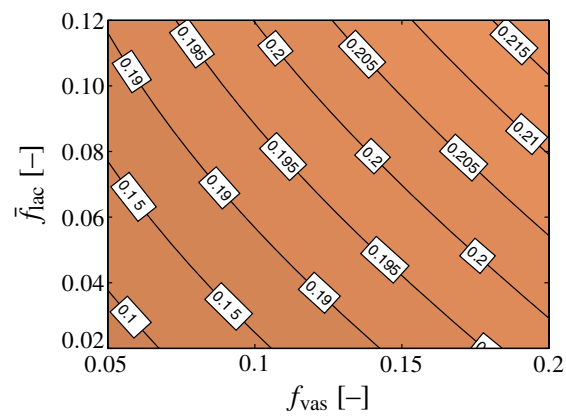

(c) $p_{\text {lac }}$ for $\Sigma=\mathrm{e}_{1} \otimes \mathrm{e}_{1}$ or $\Sigma=\mathrm{e}_{2} \otimes \mathrm{e}_{2}$, and undrained vascular pores

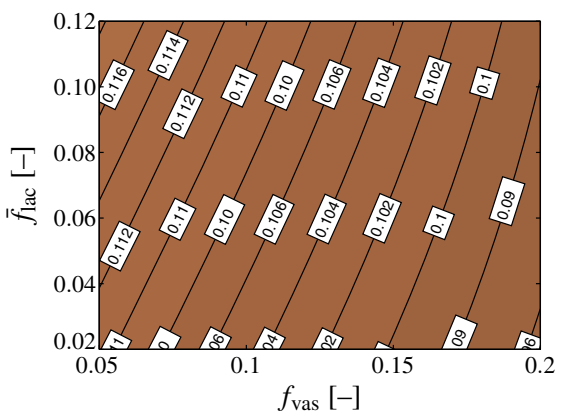

(f) $p_{\text {vas }}$ for $\Sigma=\mathrm{e}_{3} \otimes \mathrm{e}_{3}$ or, and undrained vascular pores

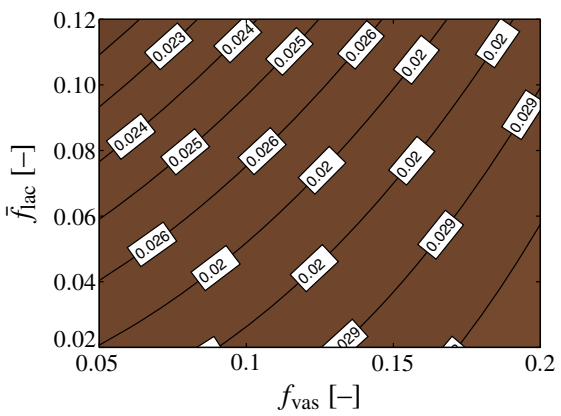

Fig. 4 Lacunar (a-d) and vascular $(\mathbf{e}, \mathbf{f})$ pore pressures building up in response to uniaxial macroscopic unit stresses; the pore pressures shown in $\mathbf{a}$ and $\mathbf{b}$ follow from evaluation of Eq. (10), whereas the pore pressures shown in $\mathbf{c}-\mathbf{f}$ follow from evaluation of Eqs. (18) and (19)

transverse direction. Also, the lacunar pore pressure buildup for the case of drained vascular pores is expectedly higher than for undrained vascular pores. This increase is directiondependent as well; while the increase is in the range of only a few percent for macroscopic stresses applied in the principal anatomical (axial) direction, it may reach more than $20 \%$ in the transverse direction. Similar deliberations hold for the strain-pore pressure relations given by Eq. (13) and (14), see Fig. 5.

In order to study this direction dependence in more detail, we consider a typical healthy cortical bone, with porosities $\bar{f}_{\text {lac }}=0.1$ and $f_{\text {vas }}=0.05$ (Buckwalter et al. 1995a; Martin et al. 1998; Cooper et al. 2007; Tai et al. 2008). Furthermore, we aim at elucidating the effect of macroscopic physiological strains. Namely, considering in vivo strain measurements (Fritton et al. 2000; Lanyon et al. 1975), a (frequently occurring) macroscopic strain in the direction of the long axis of the bone, i.e., parallel to base vector $\mathbf{e}_{3}$, is prescribed, $E_{33}=-10 \times 10^{-6}$ and $\mathbf{E}=E_{33} \mathbf{e}_{3} \otimes \mathbf{e}_{3}$. Our model predicts that for drained vascular pores, this loading causes a pressure buildup in the lacunar pores amounting to $41.05 \mathrm{kPa}$, while for undrained vascular pores the pressure that buildups in the lacunar and vascular pores, respectively, amounts to 39.93 and $34.59 \mathrm{kPa}$, respectively, see Fig. 6. On the level of the entire macroscopic RVE, this leads to a storage of elastic strain energy density amounting to
$\Psi^{\text {lac-u }}=1.1326 \mathrm{~Pa}$

in the case of undrained lacunar and drained vascular pores, and to

$\Psi^{\text {lac,vas-u }}=1.1501 \mathrm{~Pa}$

in the case of both lacunar and vascular pores being undrained, see Eqs. (40) and (43) for mathematical details. For storing the same amount of elastic energy in case of uniaxial transverse loading, $\mathbf{E}=E_{11} \mathbf{e}_{1} \otimes \mathbf{e}_{1}$, the latter strains need to be of magnitude

$E_{11}^{\text {lac-u }}=-11.7359 \times 10^{-6}$

in the case of undrained lacunar and drained vascular pores, and to

$E_{11}^{\text {lac,vas-u }}=-11.5975 \times 10^{-6}$

in the case of both lacunar and vascular pores being undrained, see Eqs. (40) and (43) for mathematical details. The corresponding lacunar pore pressures amount to 43.61 and $41.33 \mathrm{kPa}$, respectively (for drained and undrained vascular pores, respectively), while the corresponding vascular pore pressure for undrained vascular pores amounts to 
(a) $p_{\text {lac }}$ for $\mathbf{E}=\mathbf{e}_{1} \otimes \mathbf{e}_{1}$ or $\mathbf{E}=\mathbf{e}_{2} \otimes \mathbf{e}_{2}$, and drained vascular pores

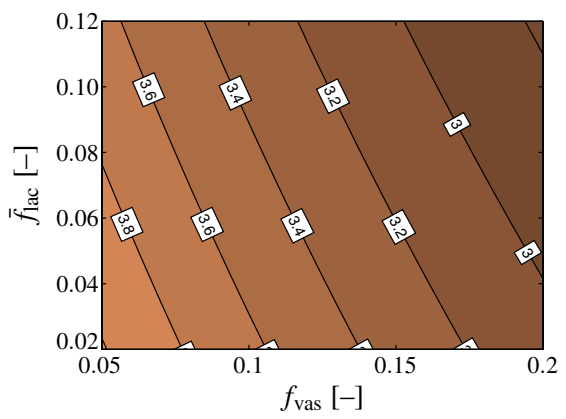

(d) $p_{\text {lac }}$ for $\mathbf{E}=\mathbf{e}_{3} \otimes \mathbf{e}_{3}$ or, and undrained vascular pores

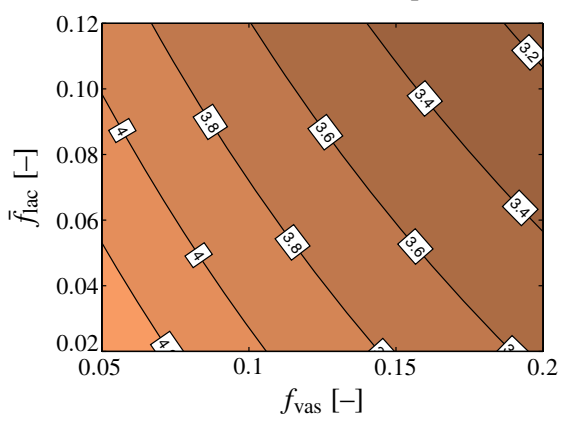

(b) $p_{\text {lac }}$ for $\mathbf{E}=\mathbf{e}_{3} \otimes \mathbf{e}_{3}$, and drained vascular pores

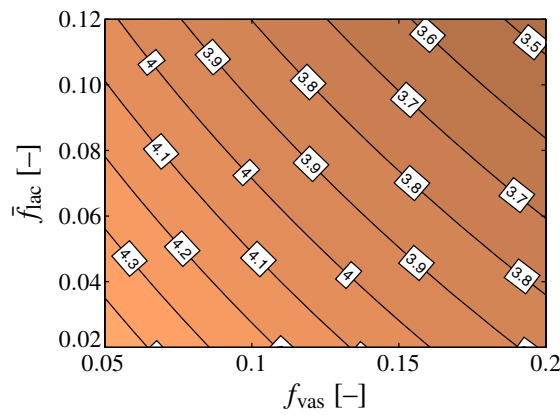

(e) $p_{\text {vas }}$ for $\mathbf{E}=\mathbf{e}_{1} \otimes \mathbf{e}_{1}$ or $\mathbf{E}=\mathbf{e}_{2} \otimes \mathbf{e}_{2}$, and undrained vascular pores

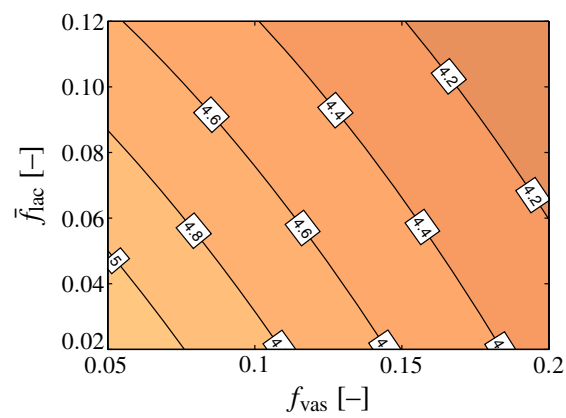

(c) $p_{\text {lac }}$ for $\mathbf{E}=\mathbf{e}_{1} \otimes \mathbf{e}_{1}$ or $\mathbf{E}=\mathbf{e}_{2} \otimes \mathbf{e}_{2}$, and undrained vascular pores

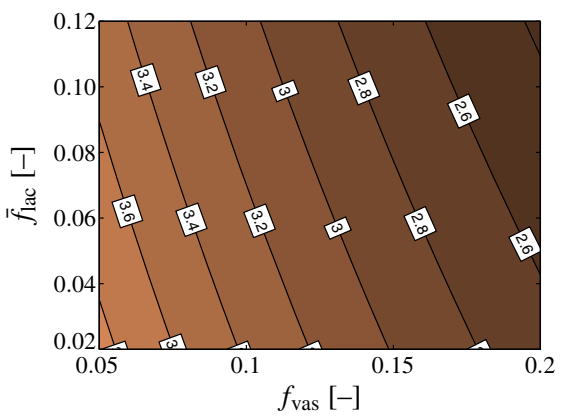

(f) $p_{\text {vas }}$ for $\mathbf{E}=\mathbf{e}_{3} \otimes \mathbf{e}_{3}$ or, and undrained vascular pores

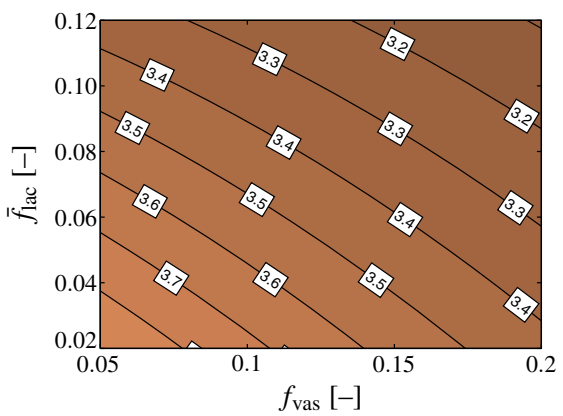

Fig. 5 Lacunar (a-d) and vascular (e, f) pore pressures, in $\mathrm{kPa}$, building up in response to uniaxial macroscopic unit microstrains; the pore pressures shown in $\mathbf{a}$ and $\mathbf{b}$ follow from evaluation of Eq. (6), whereas the pore pressures shown in $\mathbf{c}-\mathbf{f}$ follow from evaluation of Eqs. (13) and (14)

$54.84 \mathrm{kPa}$, see Fig. 6. Hence, the macrostrain-induced lacunar pore pressure is fairly independent of whether a certain amount of energy is transferred to a macroscopic RVE in terms of axial or transverse macroscopic strains. Next, we check the effect of subjecting the RVE again to the same amount of energy, but now in terms of hydrostatic macroscopic strain, $\mathbf{E}=E_{\text {hyd }}\left(\mathbf{e}_{1} \otimes \mathbf{e}_{1}+\mathbf{e}_{2} \otimes \mathbf{e}_{2}+\mathbf{e}_{3} \otimes \mathbf{e}_{3}\right)$. Accordingly, $E_{\text {hyd }}$ amounts to

$E_{\text {hyd }}^{\text {lac-u }}=-4.8111 \times 10^{-6}$

in the case of undrained lacunar and drained vascular pores, and to

$E_{\text {hyd }}^{\text {lac,vas-u }}=-4.7319 \times 10^{-6}$

in the case of both lacunar and vascular pores being undrained, see Eqs. (41) and (44) for mathematical details. The corresponding lacunar pressures amount to 55.51 and $52.62 \mathrm{kPa}$, respectively (for drained and undrained vascular pores, respectively), while the corresponding vascular pore pressure for undrained vascular pores amounts to $61.12 \mathrm{kPa}$, see Fig. 6. The differences between the extreme cases of purely uniaxial and fully hydrostatic loading applied on the macroscopic scale, in terms of their effect on the hydrostatic pressure buildup in the lacunar space, are not more than

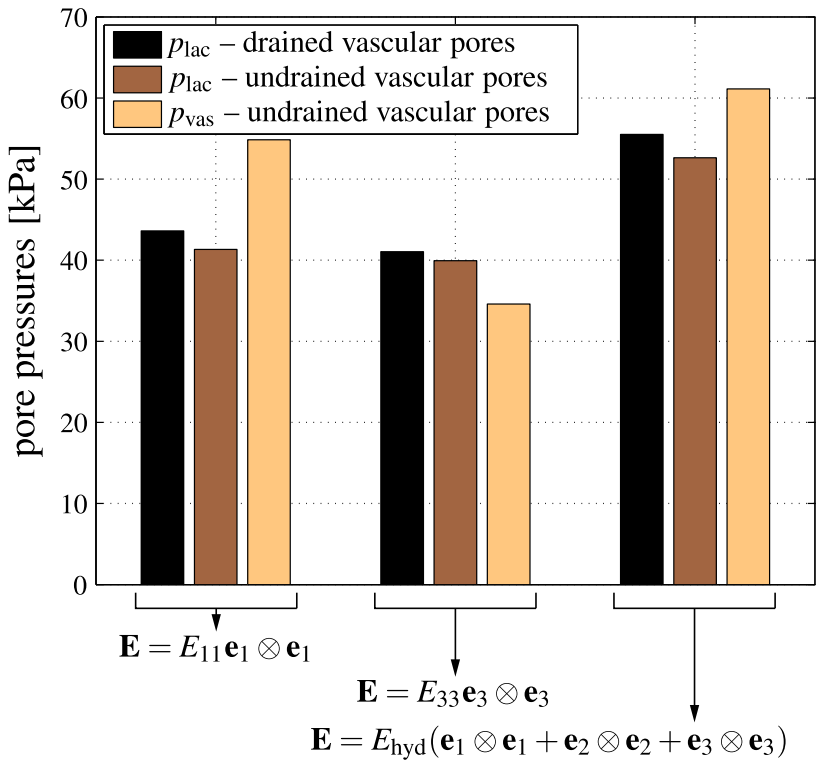

Fig. 6 Lacunar and vascular pore pressures building up in correspondence to physiological macroscopic (uniaxial and hydrostatic) strains; strain magnitudes are chosen according the requirement of strain energy density equivalence

some $20 \%$ - hence, the local hydrostatic pressure is fairly independent from the hydrostatic or non-hydrostatic nature of the macroscopic loading. 
Conclusively, under both drained and undrained conditions in the vascular pores, the osteocytes experience, irrespective of the uniaxial or hydrostatic nature of the macroscopic strain applied at physiologically relevant magnitudes and frequencies, hydrostatic pressures of a magnitude which has been shown to be very effective in stimulating various biological cells, including osteocytes (compare Table 2), see also Klein-Nulend et al. (2012). Moreover, once the vascular pores become undrained, they become pressurized at the same level as the one experienced by the lacunar pores, i.e. the one triggering cellular activity.

\subsection{Development of lacunar pore pressure due to bone aging}

The presented model can also be utilized to study the effect of degenerative diseases, such as osteoporosis, on the mechanical stimulation of osteocytes. In this context, the lacunar pores get increasingly mineralized over time, thus the lacunar porosity decreases. Assuming that the number of lacunar pores reaches a maximum at an age of 18 years, with a volume fraction of $\bar{f}_{\text {lac }}^{\text {initial }}=0.1$, the histomorphometric study implemented by Busse et al. (2010) suggests a lacunar pore volume fraction rate of $\mathrm{d} \bar{f}_{\text {lac }} / \mathrm{d} t \approx-5 \times 10^{-4} \mathrm{y}^{-1}$. The vascular porosity, in turn, increases significantly with increasing age. This increase was quantified by Cooper et al. (2007), by means of a comprehensive analysis of microcomputed tomography images gained from the femoral midshafts of subjects aged between 18 and 92 years. Cooper et al. (2007) show that the inverse of the cortical vascular porosity may decrease linearly, with $\mathrm{d}\left[\left(f_{\text {vas }}\right)^{-1}\right] / \mathrm{d} t \approx-0.42$ years $^{-1}$, thus the corresponding porosity increase follows an exponential trend. These porosity evolutions were entered into our poromicromechanical model, in order to elucidate the corresponding lacunar pore pressure changes. For the loading boundary condition, we consider a body weight of $75 \mathrm{~kg}$, and an area of the cortex in the adult femoral midshaft of $60 \mathrm{~mm}^{2}$ (Gosman et al. 2013). For getting an estimate for the stresses possibly arising in the cortex, we furthermore assume a moderate loading, amounting to $\sigma_{\text {macro, } 33} \approx-500 \mathrm{kPa}$ (when taking aforementioned numbers as reference).

Our model suggests that the lacunar pressure decreases over time, when neglecting the effect of increasing vascular porosity, see Fig. 7a. This would mean that additionally to a decreasing number of osteocytes which could sense the mechanical loading and changes thereof, the osteocytes would also sense less of the applied mechanical loading. While such trend is observed irrespective of whether the vascular pores are drained or undrained, in absolute numbers drained vascular pores induce slightly higher lacunar pore pressures. However, when neglecting the decreasing lacunar (a) mineralization of lacunae

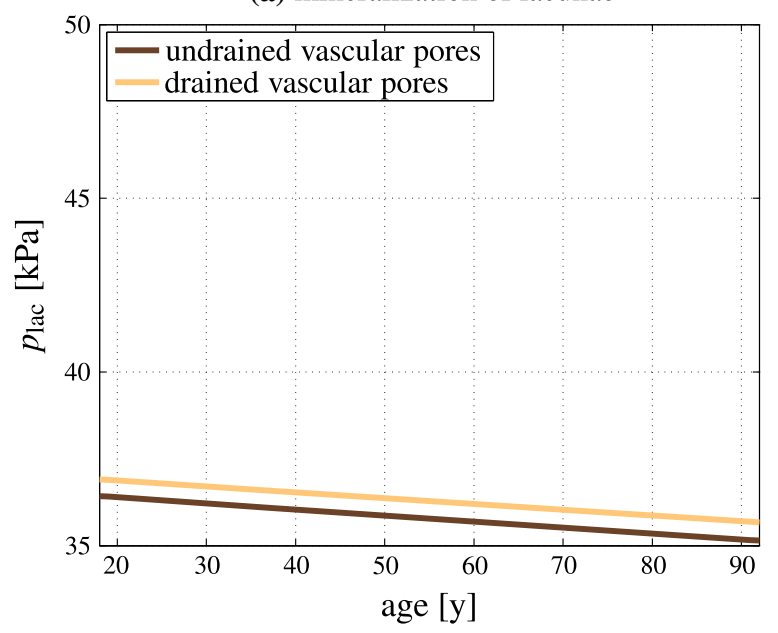

(b) increase of vascular porosity

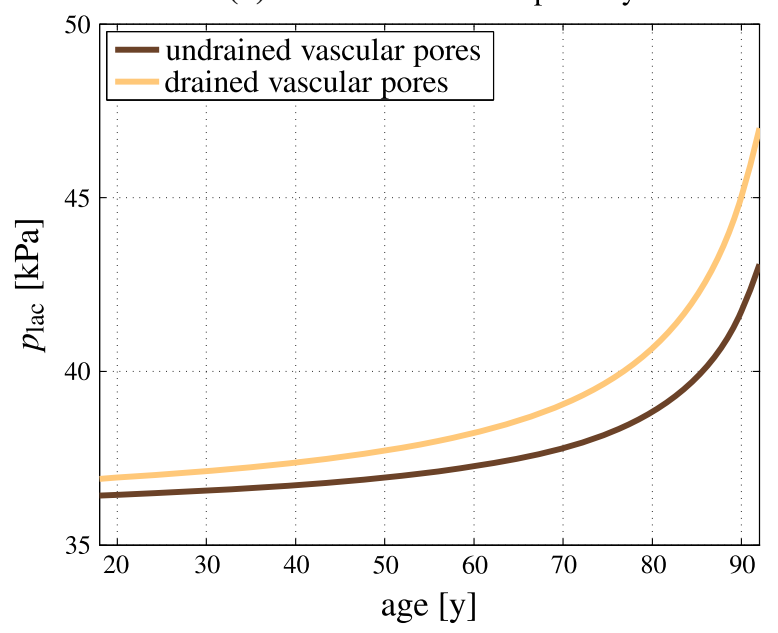

(c) combined effect

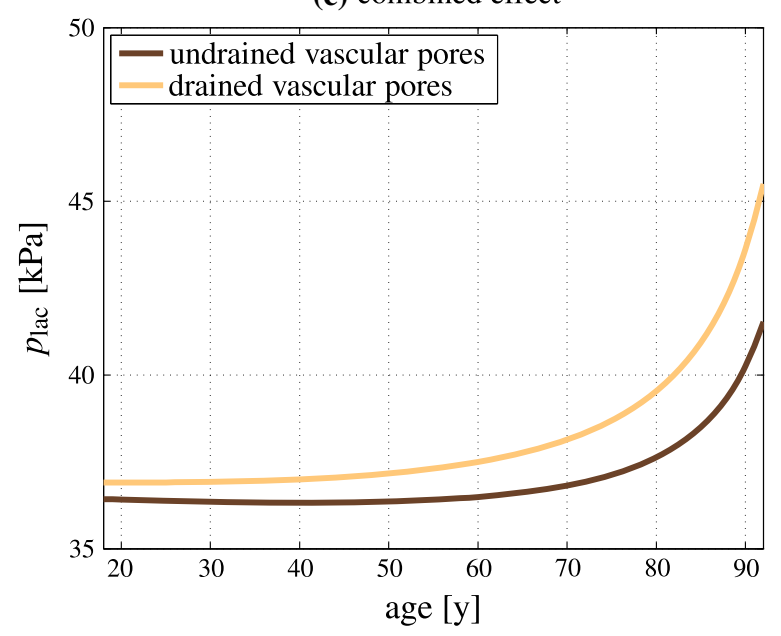

Fig. 7 Lacunar pore pressure evolution during bone aging: a the effect of decreasing lacunar porosity, $\mathbf{b}$ the effect of increasing vascular porosity, and $\mathbf{c}$ combination of $\mathbf{a}$ and $\mathbf{b}$; all computations are performed for undrained and drained vascular pores 
porosity and considering only the vascular porosity increase, we observe a significant increase in the arriving stress stimulus over time for a constant mechanical loading, see Fig. 7b. Thus, the osteocytes would be confronted with higher pore pressures that they transduce into corresponding biochemical processes. Again, the lacunar pore pressure for drained vascular pores would be higher than the pressure for undrained vascular pores. When combining both effects, see Fig. 7c, we observe a long-term increase in the lacunar pore pressures, whereas up to an age of $\approx 50$ years the until then slightly dominating effect of lacunar porosity decrease leads to an actually reduced pore pressure. However, this effect is of minor magnitude, and hardly visible in Fig. 7c.

We note that these results do not contradict the widespread notion of "old" bone being less responsive to changes of the mechanical loading than "young" bone (Duncan and Turner 1995; Turner et al. 1995). Figure 7 merely suggests that the pore pressure to which osteocytes are subjected increases with increasing age. The net response of the bone metabolism to changes of the mechanical loading, however, is not only governed by the magnitude of the mechanical stimulus, but also by the osteocyte density, viability, and connectivity. The latter quantities decrease with age, as is implied by the aging-related decrease of the lacunar porosity (Busse et al. 2010). Furthermore, in the elderly, aging-related behavioral changes of the involved cells represent an additional key factor, contributing to the reduced ability of cells to appropriately translate mechanical stimuli into corresponding bone remodeling responses, see e.g., Klein-Nulend et al. (2002), Pearson and Lieberman (2004), Leppänen et al. (2008) and Onal et al. (2013).

\section{Discussion}

Motivated by the work of Gardinier et al. (2010), which strongly suggested the occurrence of poromechanically undrained lacunar pores during physiological loading cycles, as explained in more detail in Sect. 1, we here used a wellvalidated poromicromechanical model to predict undrained lacunar pore pressures under physiological loading conditions, and the obtained pressures beautifully match those which have been experimentally shown to stimulate a variety of cells, including bone cells (see Table 2). In this context, it is most important to clearly note that such hydrostatic pressures at the lacunar pore level are triggered by strongly non-hydrostatic macroscopic stress states acting on a piece of cortical or trabecular bone.

\subsection{Poromicromechanical modeling of bone: current limitations and potential extensions}

Our current analysis aims at a reasonable and reliable estimation of the lacunar hydrostatic pressure, based on classical poroelasticity theory, and taking into account that bone is a hierarchically organized, multiporous material. Employing the concept of continuum micromechanics, the composition and morphology of (cortical or trabecular) bone is considered in terms of poromechanically governing microstructural features, such as pore shapes and porosities, as well as elastic stiffnesses of the solid phases. This way, it was shown that macroscopic loading under normal physiological conditions leads to the buildup of hydrostatic pressures in undrained lacunar pore spaces. These pressures are high enough for effectively stimulating the osteocytes residing in the lacunar pores (see the previous section). However, the present contribution leaves aside a Darcy-type transport model, which, in combination with the poromechanics model presented in this paper, would also allow for simulation of load-induced fluid transport and consolidation processes. Such transport models and estimation of respective permeabilities have been intensively discussed for the lacunar-canalicular fluid flow problem, see, e.g., Weinbaum et al. (1994), Cowin et al. (2009) and Nguyen et al. (2010).

A straightforward extension of our model, then allowing for fluid flow computations, would concern the formulation of a Darcy-type relation between the lacunar pressure gradient defined on the scale of the extravascular RVE, and a corresponding fluid flow. The underlying permeability of the lacunae-canaliculi network could be chosen based on data available in literature, see, e.g., Cardoso et al. (2013). Alternatively, a more elegant and elaborate approach could be taken, involving the explicit introduction of the canaliculi as cylindrical pores within the extracellular bone matrix. When considering the flow in the canaliculi, in a first approximation, as of the Poiseuille type, then this flow can be straightforwardly upscaled, so as to arrive at the homogenized permeability of the extralacunar matrix. Corresponding mathematical expressions have been recently derived, but used at another scale, namely at that of trabecular bone with "vascular canals" (Abdalrahman et al. 2015). At an even more elaborate stage, transport modeling may be extended to more than one pore space, in particular to the exchange of fluid between the lacunarcanalicular and the vascular pore space, as has been proposed by Cowin et al. (2009). In more detail, the Biot coefficient and moduli reported in this paper could well be fed by values emanating from the double-porous model which we have described in the present paper; while the permeability tensor could be derived from the aforementioned model of Abdalrahman et al. (2015). In a further sophistication step of the model, the flow pattern in the canaliculi could be resolved beyond Poiseuille's assumption of a parabolic velocity profile, so as to distinguish between the cell processes located at the center of the cross sections through the canaliculi, and the surrounding pericellular matrix potentially comprising also some tethering 
elements (You et al. 2004; Thompson et al. 2011; Wang et al. 2014).

\subsection{Fluid flow and undrained hydrostatic pressure as periodically alternating mechanical stimuli of bone cells; and their relations to transport phenomena}

The instances of undrained conditions are typically expected around maximum loading rates, while states in-between may well allow for fluid flow within the canaliculi, and these fluid flow cycles may express themselves in terms of cycles of so-called streaming potentials; such potential electrokinetic effects have been proposed by Eriksson (1974), Pienkowski and Pollack (1983), Pollack et al. (1984) and Weinbaum et al. (1994). In turn, the aforementioned cyclic electrical potentials do not necessarily imply transport of fluid, as bone is also known to be piezoelectric (Fukada and Yasuda 1957; Bassett 1968; Marino and Becker 1970; Marino et al. 1971; Reinish and Nowick 1975; Zhang et al. 2012) —and distinction between piezoelectric and electrokinetic effects turns out to be difficult, not to say impossible (Ahn and Grodzinsky 2009). Coincidently, piezoelectricity is sometimes regarded as important factor for biological responses (Ferreira et al. 2009; Fernández et al. 2012).

Other experiments which have been employed for arguing in favor of significant canalicular fluid flow, concern tracer molecules which were injected into bone specimens. Then, histological studies were carried out in bone cross sections with and without additional mechanical loading applied, e.g., through four point-bending protocols (Knothe Tate et al. 2000). It turned out that mechanical loading enhanced the tracer transport, up to $30 \%$ when estimated from a threshold-based voxel analysis of photomicrographs-see Knothe Tate and Knothe (2000) for details, especially Table 2 of this reference- and by not more than $5 \%$ when quantified through a confocal microscopy-based study—see Figure 4 of Knothe Tate and Knothe (2000).

The popular explanation for transport of tracer molecules, which has been advocated more and more explicitly over time (Seliger 1970; Knothe Tate and Knothe 2000; Knothe Tate et al. 2000; Wang et al. 2005; Zhou et al. 2008; Kwon and Frangos 2010; Price et al. 2011; Kwon et al. 2012), is that without mechanical loading, only diffusive transport is taking place, while mechanical loading might induce an additional convective transport portion, thus enhancing the overall transport of tracer through the investigated bone tissue. In order to further discuss this popular explanation, it is quite instructive to more closely examine the load cases which were actually applied to the system studied by Knothe Tate and Knothe (2000): Their strain gauge recordings show that loading pulses lasting around $2 \mathrm{~s}$ are intermitted by 13 -s-long quiescent periods where no (macroscopic) strain was measured at all. Since absence of such
Table 3 Distribution of characteristic loading times related to the ex vivo compression tests on the forelimb of the Swiss alpine sheep, in particular on the compact part of the metacarpus therein, conducted by Knothe Tate and Knothe (2000); I: $T_{\text {load }}<0.1 \mathrm{~s}$, II: $0.1 \mathrm{~s} \leq T_{\text {load }}<1 \mathrm{~s}$, III: $1 \mathrm{~s} \leq T_{\text {load }}<10 \mathrm{~s}$, and IV: $10 \mathrm{~s} \leq T_{\text {load }}$

\begin{tabular}{lclll}
\hline Load cycle & I $(\%)$ & II $(\%)$ & III $(\%)$ & IV (\%) \\
\hline 1 & 8 & 65 & 27 & 0 \\
2 & 11 & 79 & 10 & 0 \\
3 & 13 & 84 & 3 & 0 \\
4 & 13 & 87 & 0 & 0 \\
5 & 12 & 70 & 18 & 0 \\
6 & 10 & 63 & 27 & 0 \\
7 & 8 & 78 & 14 & 0 \\
\hline
\end{tabular}

strain provokes neither undrained hydrostatic pressure nor pore fluid flow, we restrict our analysis of the applied load cycles to the 2 s-intervals where actual strains were recorded. The results are summarized in Table 3: the most frequently occurring characteristic times range from 0.1 to $1 \mathrm{~s}$, longer times cover only a few percent of the entity of such times, and not a single one of the characteristic times exceeds $10 \mathrm{~s}$. This, together with the arguments given in the Introduction (see Sect. 1), qualifies fluid flow as a kind of secondary phenomenon taking place in the study of Knothe Tate and Knothe (2000), provoking the obvious question what drives then the enhanced tracer transport under oscillatory loading.

Seeking such an explanation, we recall some fundamental principles of physical chemistry: When polarized fluids, such as water, are adjacent to charged surfaces, such as the experimentally observed mineral-rich surfaces of extracellular bone tissue (Lees et al. 1984; Lees and Prostak 1988; Lees et al. 1994; Sasaki et al. 2002), the water molecules become ordered, leading to a substance called "layered" or "structured" water (Pollack 2001, 2013), which exhibits increased viscosity and decreased diffusivity (Ichikawa et al. 2002; Pivonka et al. 2004), when compared to fully disordered "bulk water". The zone of layered water, which is also called exclusion zone (Pollack 2013), may reach thicknesses of up to several milimeters (Florea et al. 2014), which recently allowed for explaining the permeability properties of trabecular bone (Abdalrahman et al. 2015). Remarkably, for a variety of biological material systems (Green and Otori 1970; Wilson and Dietschy 1974; Barry and Diamond 1984; Pollack and Clegg 2008) it has been shown that stirring of layered fluids led to a diffusivity re-gain. Thus, mechanical excitation of the bone fluid in form of oscillating hydrostatic pressures resulting from macroscopic loading might result in partial "destruction" of the water layering effect, and therefore explain the transient acceleration of tracer transport under oscillating mechanical loading. Once the diffusion process is completed, however, no difference between 
loaded and unloaded configurations would be expected, as was indeed found experimentally by Knothe Tate and Knothe (2000).

\subsection{Summary and outlook}

Conclusively, no major experimental findings necessarily contradict the potential occurrence of undrained lacunar pore pressure occurring during physiological load cycles. Then, given the novel poromicromechanical results presented in the present paper together with all the experimental evidence condensed into Table 2, this pressure appears as a prime candidate for being used as a mechanical stimulus in the context of multiscale mechanobiological approaches linking poromicromechanics and mathematical systems biology (Scheiner et al. 2013, 2014).

Acknowledgments Financial support by the European Research Council (ERC), in the framework of the project Multiscale poromicromechanics of bone materials, with links to biology and medicine (project number FP7-257023), is gratefully acknowledged. Dr. Pivonka gratefully acknowledges support by the Saskatchewan-CIHR Regional Partnership Program. Furthermore, the authors acknowledge the support of Prof. John G. Clement and Mr. David Thomas, Melbourne Dental School, The University of Melbourne, Australia, for providing the microradiographs of the femur cross sections shown in Fig. 2, taken from the Melbourne Femur Collection. Finally, the authors thank the reviewers of this paper for providing critical, yet constructive comments, leading to substantial improvement of this paper in the course of the revision process.

Open Access This article is distributed under the terms of the Creative Commons Attribution 4.0 International License (http://creativecomm ons.org/licenses/by/4.0/), which permits unrestricted use, distribution, and reproduction in any medium, provided you give appropriate credit to the original author(s) and the source, provide a link to the Creative Commons license, and indicate if changes were made.

\section{Appendix: Definition of poroelastic quantities}

\section{Upscaling (drained) stiffness, Biot tensors, and Biot moduli}

We start with considering the constituents of the extravascular RVE (see Fig. 3), i.e., the extralacunar matrix and the lacunar pores, as poroelastic materials, with constitutive laws reading as

$\boldsymbol{\sigma}_{i}=\mathbb{C}_{i}: \boldsymbol{\varepsilon}_{i}-\mathbf{b}_{i} p_{i}, \quad i \in\{$ exlac, lac $\}$,

where $\sigma_{i}$ is the stress tensor of constituent $i, \boldsymbol{\varepsilon}_{i}$ is the strain tensor of constituent $i, \mathbb{C}_{i}$ is the drained stiffness tensor of constituent $i, \mathbf{b}_{i}$ is the Biot tensor of constituent $i$, and $p_{i}$ is the pressure to which constituent $i$ is exposed. More specifically, the extralacunar bone matrix is considered as purely solid phase, so that $\mathbf{b}_{\text {exlac }}=0 \Rightarrow \sigma_{\text {exlac }}=\mathbb{C}_{\text {exlac }}: \boldsymbol{\varepsilon}_{\text {exlac }}$

while the lacunar pores do not exhibit any solid stiffness, and are just subjected to a pore pressure, so that

$\mathbf{b}_{\text {lac }}=\mathbf{1} \Rightarrow \sigma_{\text {lac }}=-\mathbf{1} p_{\text {lac }}$

where 1 denotes the second-order unit tensor. The corresponding "homogenized" material behavior of the extravascular bone material follows the standard relation of continuum micromechanics (Zaoui 2002; Dormieux et al. 2006; Hellmich et al. 2009):

$\sigma_{\text {exvas }}=\mathbb{C}_{\text {exvas }}: \varepsilon_{\text {exvas }}-\mathbf{b}_{\text {exvas }}^{\text {lac }} p_{\text {lac }}$,

with

$\mathbb{C}_{\text {exvas }}=\bar{f}_{\text {exlac }} \mathbb{C}_{\text {exlac }}: \mathbb{A}_{\text {exlac }}$

and

$\mathbf{b}_{\mathrm{exvas}}^{\mathrm{lac}}=\bar{f}_{\mathrm{lac}} \mathbf{1}: \mathbb{A}_{\mathrm{lac}}$,

whereby $\bar{f}_{\text {lac }}$ and $\bar{f}_{\text {exlac }}$ are the volume fractions of the lacunar pore space and the extralacunar space, quantified within the RVE of extravascular bone matrix, compare Fig. 3. Furthermore, $\mathbb{A}_{\text {exlac }}$ and $\mathbb{A}_{\text {lac }}$ are the concentration (or "downscaling") tensors relating extravascular strains to those in the extralacunar and (drained) lacunar spaces,

$\boldsymbol{\varepsilon}_{i}=\mathbb{A}_{i}: \boldsymbol{\varepsilon}_{\text {exvas }}, \quad i \in\{$ lac, exlac $\}$.

These concentration tensors quantify the micromechanical interactions between a transversely isotropic extralacunar matrix of stiffness $\mathbb{C}_{\text {exlac}}$, and spherical (drained) lacunar pores. They are derived from combination of matrixinfluence problems of the Eshelby-Laws type (Eshelby 1957; Laws 1977), with the (micro) strain average rule valid for the extravascular RVE. The corresponding dependence of $\mathbb{A}_{\text {exlac }}$ and $\mathbb{A}_{\text {lac }}$ on $\bar{f}_{\text {lac }}$ and $\mathbb{C}_{\text {exlac }}$ is given in great mathematical detail in Morin and Hellmich (2014), where the extralacunar space is called "extracellular space". The stiffness of the latter space is a function of its mass density only, due to the existence of experimentally corroborated "universal" bone composition rules between organic, mineral, and water contents (Vuong and Hellmich 2011), as well as of fibrillar organization rules depending on the mineralization and hydration degrees only (Hellmich and Ulm 2003; Morin and Hellmich 2013; Morin et al. 2013). These rules hold irrespective of species, age, or anatomical location, as long as the organism is not drug-treated. Accordingly, an extracellular mass density of $1.93 \mathrm{~g} / \mathrm{cm}^{3}$, typical for human femur 
(Lees et al. 1983), results, according to the very comprehensively experimentally validated microelasticity theory as summarized in (Morin and Hellmich 2014), in an extralacunar stiffness of

$\mathbb{C}_{\text {exlac }}=\left(\begin{array}{cccccc}22.88 & 8.93 & 10.14 & 0 & 0 & 0 \\ 8.93 & 22.88 & 10.14 & 0 & 0 & 0 \\ 10.14 & 10.14 & 29.60 & 0 & 0 & 0 \\ 0 & 0 & 0 & 14.72 & 0 & 0 \\ 0 & 0 & 0 & 0 & 14.72 & 0 \\ 0 & 0 & 0 & 0 & 0 & 13.96\end{array}\right)$ GPa

We take this stiffness tensor as the basis for all computations given in the present paper-noting that it is conveniently close to the famous direct measurements on human femur performed by Ashman et al. (1984).

One hierarchical level further up, i.e., within an RVE of macroscopic bone material (see Fig. 3), the extravascular bone matrix plays the role of a (poroelastic) phase with state equation (26), the other phase being the vascular pores, characterized by

$\mathbf{b}_{\mathrm{vas}}=\mathbf{1} \Rightarrow \boldsymbol{\sigma}_{\mathrm{vas}}=-\mathbf{1} p_{\mathrm{vas}}$.

Applying homogenization rules analogous to those having led to Eqs. (26)-(28), we upscale Eqs. (26) and (31) one level up, so as to arrive at Eq. (2), whereby

$\mathbf{b}_{\text {macro }}^{\text {lac }}=\bar{f}_{\text {exvas }} \mathbf{b}_{\text {exvas }}^{\text {lac }}: \mathbb{A}_{\text {exvas }}$,

and

$\mathbf{b}_{\text {macro }}^{\mathrm{vas}}=\bar{f}_{\text {vas }} \mathbf{1}: \mathbb{A}_{\text {vas }}$,

with $\mathbb{A}_{\text {exvas }}$ and $\mathbb{A}_{\text {vas }}$ as the concentration tensors downscaling strains from the macroscopic to the extravascular and (drained) vascular spaces,

$\boldsymbol{\varepsilon}_{i}=\mathbb{A}_{i}: \mathbf{E}, \quad i \in\{$ vas, exvas $\}$

Mathematical details on these concentration tensors can again be found in (Morin and Hellmich 2014).

The Biot moduli occurring in the state equations for the porosity changes, Eqs. (3) and (4), can be derived from the superposition of pore pressure and (macro) strain-related load cases in conjunction with the stress average rule (Dormieux et al. 2006; Hellmich et al. 2009). In case of the extravascular space, we arrive at

$\frac{1}{N_{\text {exvas }}}=-\mathbf{b}_{\text {lac }}:\left(\mathbb{C}_{\text {excell }}\right)^{-1}:\left(\bar{f}_{\text {lac }} \mathbf{b}_{\text {lac }}-\mathbf{b}_{\text {exvas }}^{\text {lac }}\right)$,

which then enters the following expressions for the Biot moduli on the macroscopic scale

$$
\begin{aligned}
& \frac{1}{N_{\text {macro }}^{\text {lacl,ac }}=}-\mathbf{b}_{\text {exvas }}^{\text {lac }}:\left(\mathbb{C}_{\text {exvas }}\right)^{-1} \\
&:\left(f_{\text {exvas }} \mathbf{b}_{\text {exvas }}^{\text {lac }}-\mathbf{b}_{\text {macro }}^{\text {lac }}\right)+\frac{f_{\text {exvas }}}{N_{\text {exvas }}} \\
& \frac{1}{N_{\text {macro }}^{\text {vasas }}=}-\mathbf{b}_{\text {exvas }}^{\text {vas }}:\left(\mathbb{C}_{\text {exvas }}\right)^{-1}:\left(f_{\text {vas }} \mathbf{b}_{\text {vas }}-\mathbf{b}_{\text {macro }}^{\text {vas }}\right), \\
& \frac{1}{N_{\text {macro }}^{\text {lac,vas }}=}-\mathbf{b}_{\text {exvas }}^{\text {lac }}:\left(\mathbb{C}_{\text {exvas }}\right)^{-1}:\left(f_{\text {vas }} \mathbf{b}_{\text {vas }}-\mathbf{b}_{\text {macro }}^{\text {vas }}\right) .
\end{aligned}
$$

\section{Elastic energy stored in the macroscopic RVE of bone}

In the case of undrained lacunar and drained vascular pores, the elastic energy stored in a macroscopic RVE of bone amounts to

$\Psi^{\text {lac-u }}=\frac{1}{2} \mathbf{E}: \mathbb{C}_{\text {macro }}^{\text {lac-u }}: \mathbf{E}$,

with $\mathbb{C}_{\text {macro }}^{\text {lac-u }}$ following Eq. (9). For uniaxial strain $\mathbf{E}=$ $E_{i i} \mathbf{e}_{i} \otimes \mathbf{e}_{i}, i=1,2,3$, Eq. (39) reduces to

$\Psi^{\mathrm{lac}-\mathrm{u}}=\frac{1}{2} C_{\mathrm{macro}, i i i i}^{\mathrm{lac}}\left(E_{i i}\right)^{2}$.

For hydrostatic strain, $\mathbf{E}=E_{\text {hyd }} \sum_{i=1}^{3} \mathbf{e}_{i} \otimes \mathbf{e}_{i}$, Eq. (39) reduces to

$\Psi^{\text {lac-u }}=\frac{1}{2}\left(E_{\mathrm{hyd}}\right)^{2} \sum_{i=1}^{3} \sum_{j=1}^{3} C_{\text {macro }, i i j j}^{\text {lac-u }}$.

In the case of both lacunar and vascular pores being undrained, the elastic energy stored in a macroscopic RVE of bone amounts to

$\Psi^{\text {lac,vas-u }}=\frac{1}{2} \mathbf{E}: \mathbb{C}_{\text {macro }}^{\text {lac,vas-u }}: \mathbf{E}$,

with $\mathbb{C}_{\text {macro }}^{\text {lac,vas-u }}$ following Eq. (17). For uniaxial strain $\mathbf{E}=$ $E_{i i} \mathbf{e}_{i} \otimes \mathbf{e}_{i}, i=1,2,3$, Eq. (42) reduces to

$\Psi^{\text {lac,vas-u }}=\frac{1}{2} C_{\text {macro, }, i i i i}^{\text {lac, vas-u }}\left(E_{i i}\right)^{2}$.

For hydrostatic strain, $\mathbf{E}=E_{\text {hyd }} \sum_{i=1}^{3} \mathbf{e}_{i} \otimes \mathbf{e}_{i}$, Eq. (42) reduces to

$\Psi^{\text {lac,vas-u }}=\frac{1}{2}\left(E_{\mathrm{hyd}}\right)^{2} \sum_{i=1}^{3} \sum_{j=1}^{3} C_{\text {macro }, i i j j}^{\text {lac, vas-u }}$. 


\section{References}

Abdalrahman T, Scheiner S, Hellmich C (2015) Is trabecular bone permeability governed by molecular ordering-induced fluid viscosity gain? Arguments from re-evaluation of experimental data in the framework of homogenization theory. J Theor Biol 365:433-444

Abousleiman Y, Cheng A-D, Cui L, Detournay E, Roegiers J-C (1996) Mandel's problem revisited. Géotechnique 46(2):187-195

Ahn A, Grodzinsky A (2009) Relevance of collagen piezoelectricity to "Wolff's law": a critical review. Med Eng Phys 31(7):733-741

Ashman R, Cowin S, Van Buskirk W, Rice J (1984) A continuous wave technique for the measurement of the elastic properties of cortical bone. J Biomech 17(5):349-361

Auriault J-L, Boutin C, Geindreau C (2009) Homogenization of coupled phenomena in heterogeneous media. Wiley-Iste

Bader T, Hofstetter K, Hellmich C, Eberhardsteiner J (2011) The poroelastic role of water in cell walls of the hierarchical composite "softwood". Acta Mech 217(1-2):75-100

Barry P, Diamond J (1984) Effects of unstirred layers on membrane phenomena. Physiol Rev 64(3):763-871

Bassett C (1968) Biological significance of piezoelectricity. Calcif Tissue Res 1(4):252-272

Bergmann G, Graichen F, Rohlmann A (1993) Hip joint loading during walking and running, measured in two patients. J Biomech 26(8):969-990

Biot M (1941) General theory of three-dimensional consolidation. J Appl Phys 12(2):155-164

Boutroy S, Bouxsein M, Munoz F, Delmas P (2005) In vivo assessment of trabecular bone microarchitecture by high-resolution peripheral quantitative computed tomography. J Clin Endocrinol Metab 90(12):6508-6515

Boutroy S, Vilayphiou N, Roux J-P, Delmas P, Blain H, Chapurlat R, Chavassieux P (2011) Comparison of 2D and 3D bone microarchitecture evaluation at the femoral neck, among postmenopausal women with hip fracture or hip osteoarthritis. Bone 49(5):10551061

Brighton C, Fisher J, Levine S, Corsetti J, Reilly T, Landsman A, Williams J, Thibault L (1996) The biochemical pathway mediating the proliferative response of bone cells to a mechanical stimulus. J Bone Joint Surg 78A(9):1337-1347

Brookes M, Revell W (1998) Blood supply of bone. Springer, London

Bryant J (1983) The effect of impact on the marrow pressure of long bones in vitro. J Biomech 16(8):659-665

Bryant J (1988) On the mechanical function of marrow in long bones. Eng Med 17(2):55-58

Buckwalter J, Cooper R (1987). Instructional course lectures 36, chapter bone structure and function, pp 27-48. American Academy of Orthopaedic Surgeons, Rosemont IL, USA

Buckwalter J, Glimcher M, Cooper R, Recker R (1995) Bone biology. Part I: structure, blood supply, cells, matrix, and mineralization. J Bone Joint Surg Ser A 77(8):1256-1275

Buckwalter J, Glimcher M, Cooper R, Recker R (1995) Bone biology. Part II. Formation form, modeling, remodeling, and regulation of cell function. J Bone Joint Surg Ser A 77(8):1276-1289

Burr D, Milgrom C, Fyhrie D, Forwood M, Nyska M, Finestone A, Hoshaw S, Saiag E, Simkin A (1996) In vivo measurement of human tibial strains during vigorous activity. Bone 18(5):405-410

Busse B, Djonic D, Milovanovic P, Hahn M, Püschel K, Ritchie R, Djuric M, Amling M (2010) Decrease in the osteocyte lacunar density accompanied by hypermineralized lacunar occlusion reveals failure and delay of remodeling in aged human bone. Aging Cell 9(6): 1065-1075

Byers S, Moore A, Byard R, Fazzalari N (2000) Quantitative histomorphometric analysis of the human growth plate from birth to adolescence. Bone 27(4):495-501
Cameron J, Skofronick J, Grant R (1999) Physics of the body, 2nd edn. Medical Physics Publishing

Cardoso L, Fritton S, Gailani G, Benalla M, Cowin S (2013) Advances in assessment of bone porosity, permeability and interstitial fluid flow. J Biomech 46(2):253-265

Chen H, Zhou X, Shoumura S, Emura S, Bunai Y (2010) Age- and gender-dependent changes in three-dimensional microstructure of cortical and trabecular bone at the human femoral neck. Osteoporos Int 21(4):627-636

Colloca M, Blanchard R, Hellmich C, Ito K, van Rietbergen B (2014) A multiscale analytical approach for bone remodeling simulations: linking scales from collagen to trabeculae. Bone 64:303-313

Cooper D, Thomas C, Clement J, Turinsky A, Sensen C, Hallgrímson B (2007) Age-dependent change in the 3D structure of cortical porosity at the human femoral midshaft. Bone 40(4):957-965

Cooper D, Turinsky A, Sensen C, Hallgrímsson B (2003) Quantitative $3 \mathrm{D}$ analysis of the canal network in cortical bone by microcomputed tomography. Anat Rec Part B New Anat 274(1):169-179

Coussy O (2004) Poromechanics. Wiley, London

Cowin S (1999) Bone poroelasticity. J Biomech 32(3):217-238

Cowin S, Gailani G, Benalla M (2009) Hierarchical poroelasticity: movement of interstitial fluid between porosity levels in bones. Philos Trans R Soc Lond A Math Phys Eng Sci 367(1902):34013444

Dormieux L, Kondo D, Ulm F-J (2006) Microporomechanics. Wiley, London

Drugan W, Willis J (1996) A micromechanics-based nonlocal constitutive equation and estimates of representative volume element size for elastic composites. J Mech Phys Solids 44(4):497-524

Duncan R, Turner C (1995) Mechanotransdution and the functional response of bone to mechanical strain. Calcif Tissue Int 57(5):344358

Ebacher V, Guy P, Oxland T, Wang R (2012) Sub-lamellar microcracking and roles of canaliculi in human cortical bone. Acta Biomater 8(3): 1093-1100

Eberhardsteiner L, Hellmich C, Scheiner S (2014) Layered water in crystal interfaces as source for bone viscoelasticity: arguments from a multiscale approach. Comput Methods Biomech Biomed Eng 17(1):48-63

Eriksson C (1974) Streaming potentials and other water-dependent effects in mineralized tissues. Ann NY Acad Sci 238:321-338

Eshelby J (1957) The determination of the elastic field of an ellipsoidal inclusion, and related problems. Proc R Soc Lond Ser A 241:376396

Fernández J, García-Aznar J, Martinéz R (2012) Piezoelectricity could predict sites of formation/resorption in bone remodelling and modelling. J Theor Biol 292:86-92

Ferreira A, González G, González R, Feijoo J, Lira-Olivares J, NorisSuárez K (2009) Bone collagen role in piezoelectric mediated remineralization. Acta Microsc 18(3):278-286

Florea D, Musa S, Huyghe J, Wyss H (2014) Long-range repulsion of colloids driven by ion exchange and diffusiophoresis. Proc Natl Acad Sci USA 111(18):6554-6559

Fritsch A, Hellmich C (2007) 'Universal' microstructural patterns in cortical and trabecular, extracellular and extravascular bone materials: micromechanics-based prediction of anisotropic elasticity. J Theor Biol 244(4):597-620

Fritsch A, Hellmich C, Dormieux L (2009) Ductile sliding between mineral crystals followed by rupture of collagen crosslinks: experimentally supported micromechanical explanation of bone strength. J Theor Biol 260(2):230-252

Fritton S, McLeod K, Rubin C (2000) Quantifying the strain history of bone: spatial uniformity and self-similarity of low-magnitude strains. J Biomech 33(3):317-325

Fukada E, Yasuda I (1957) On the piezoelectric effect of bone. J Phys Soc Jpn 12(10):1158-1162 
Gardinier J, Majumdar S, Duncan R, Wang L (2009) Cyclic hydraulic pressure and fluid flow differentially modulate cytoskeleton reorganization in MC3T3 osteoblasts. Cell Mol Bioeng 2(1):133143

Gardinier J, Townend C, Jen K-P, Wu Q, Duncan R, Wang L (2010) In situ permeability measurement of the mammalian lacunarcanalicular system. Bone 46(4):1075-1081

Gosman J, Hubbell Z, Shaw C, Ryan T (2013) Development of cortical bone geometry in the human femoral and tibial diaphysis. Anat Rec 296(5):774-787

Green K, Otori T (1970) Direct measurement of membrane unstirred layers. J Physiol 207(1):93-102

Grimal Q, Rus G, Parnell W, Laugier P (2011) A two-parameter model of the effective elastic tensor for cortical bone. J Biomech 44(8):1621-1625

Hellmich C, Celundova D, Ulm F-J (2009) Multiporoelasticity of hierarchically structured materials: micromechanical foundations and application to bone. J Eng Mech 135(5):382-394

Hellmich C, Kober C, Erdmann B (2008) Micromechanics-based conversion of CT data into anisotropic elasticity tensors, applied to FE simulations of a mandible. Ann Biomed Eng 36(1):108122

Hellmich C, Ulm F-J (2003) Average hydroxyapatite concentration is uniform in the extracollagenous ultrastructure of mineralized tissues: evidence at the 1-10 $\mu \mathrm{m}$ scale. Biomech Model Mechanobiol 2(1):21-36

Hellmich C, Ulm F-J (2005a) Drained and undrained poroelastic properties of healthy and pathologial bone: A poro-micromechanical investigation. Transp Porous Media 58:243-268

Hellmich C, Ulm F-J (2005b) Microporodynamics of bones: prediction of the "Frenkel-Biot" slow compressional wave. J Eng Mech 131(9):918-927

Hellmich C, Ulm F-J, Dormieux L (2004) Can the diverse elastic properties of trabecular and cortical bone be attributed to only a few tissue-independent phase properties and their interactions? - arguments from a multiscale approach. Biomech Model Mechanobiol 2(4):219-238

Henstock J, Rotherham M, Rose J, El Haj A (2013) Cyclic hydrostatic pressure stimulates enhanced bone development in the foetal chick femur in vitro. Bone 53(2):468-477

Hill R (1963) Elastic properties of reinforced solids: some theoretical principles. J Mech Phys Solids 11(5):357-372

Hill R (1965) Continuum micro-mechanics of elastoplastic polycrystals. J Mech Phys Solids 13(2):89-101

Hoang S, Abousleiman Y (2009) Poroviscoelastic two-dimensional anisotropic solution with application to articular cartilage testing poroviscoelastic two-dimensional anisotropic solution with application to articular cartilage testing. J Eng Mech 135(5):367-374

Hosokawa A, Otani T (1997) Ultrasonic wave propagation in bovine cancellous bone. J Acoust Soc Am 101(1):558-562

Huyghe J, Molenaar M, Baajens F (2007) Poromechanics of compressible charged porous media using the theory of mixtures. J Biomech Eng 129(5):776-785

Ichikawa Y, Kawamura K, Fujii N, Nattavut T (2002) Molecular dynamics and multiscale homogenization analysis of seepage/diffusion problem in bentonite clay. Int J Numer Methods Eng 54(12):17171749

Imamura K, Ozawa H, Hiraide T, Takahashi N, Shibasaki Y, Fukuhura T, Suda T (1990) Continuously applied compressive pressure induces bone resorption by a mechanism involving prostaglandin E2 synthesis. J Cell Physiol 144(2):222-228

Jacobs C, Temiyasathit S, Castillo A (2010) Osteocyte mechanobiology and pericellular mechanics. Annu Rev Biomed Eng 12:369400

Kessel R, Kardon R (1979) A text-atlas of scanning electron microscopy. W. H. Freeman \& Co, San Francisco
Klein-Nulend J, Bacabac R, Bakker A (2012) Mechanical loading and how it affects bone cells: the role of the osteocyte cytoskeleton in maintaining our skeleton. Eur Cells Mater 24:278-291

Klein-Nulend J, Sterck J, Semeins C, Lips P, Joldersma M, Baart J, Burger E (2002) Donor age and mechanosensitivity of human bone cells. Osteoporos Int 13(2):137-146

Klein-Nulend J, Van der Plas A, Semeins C, Ajubi N, Frangos J, Nijweide P, Burger E (1995) Sensitivity of osteocytes to biomechanical stress in vitro. FASEB J 9(5):441-445

Knothe Tate M (2003) "Whither flows the fluid in bone?" an osteocyte's perspective. J Biomech 36(10):1409-1424

Knothe Tate M, Knothe U (2000) An ex vivo model to study transport processes and fluid flow in loaded bone. J Biomech 33(2):247-254

Knothe Tate M, Steck R, Forwood M, Niederer P (2000) In vivo demonstration of load-induced fluid flow in the rat tibia and its potential implications for processes associated with functional adaptation. J Exp Biol 203(18):2737-2745

Kutzner I, Heinlein B, Graichen F, Bender A, Rohlmann A, Halder A, Beier A, Bergmann G (2010) Loading of the knee joint during activities of daily living measured in vivo in five subjects. $J$ Biomech 43(11):2164-2173

Kwon R, Frangos J (2010) Quantification of lacunar-canalicular interstitial fluid flow through computational modeling of fluorescence recovery after photobleaching. Cell Mol Bioeng 3(3):296-306

Kwon R, Meays D, Meilan A, Jones J, Miramontes R, Kardos N, Yeh JC, Frangos J (2012) Skeletal adaptation to intramedullary pressureinduced interstitial fluid flow is enhanced in mice subjected to targeted osteocyte ablation. PLoS One 7(3):e33336

Lanyon L, Hampson W, Goodship A, Shah J (1975) Bone deformation recorded in vivo from strain gauges attached to the human tibial shaft. Acta Orthop 46(2):256-268

Laws N (1977) The determination of stress and strain concentrations at an ellipsoidal inclusion in an anisotropic material. J Elast 7(1):9197

Lee K, Roh H-S, Yoon S (2003) Correlations between acoustic properties and bone density in bovine cancellous bone from 0.5 to 2 MHz. J Acoust Soc Am 113(5):2933-2938

Lees S, Ahern J, Leonard M (1983) Parameters influencing the sonic velocity in compact calcified tissues in various species. J Acoust Soc Am 74(1):28-33

Lees S, Bonar L, Mook H (1984) A study of dense mineralized tissue by neutron diffraction. Int J Biol Macromol 6(6):321-326

Lees S, Cleary P, Heeley JD, Gariepy E (1979) Distribution of sonic plesio-velocity in a compact bone sample. J Acoust Soc Am 66(3):641-646

Lees S, Prostak K (1988) The locus of mineral crystallites in bone. Connect Tissue Res 18(1):41-54

Lees S, Prostak K, Ingle V, Kjoller K (1994) The loci of mineral in turkey leg tendon as seen by atomic force microscope and electron microscopy. Calcif Tissue Int 55(3):180-189

Leppänen $\mathrm{O}$, Sievänen H, Jokihaara J, Pajamäki I, Kannus P, Järvinen T (2008) Pathogenesis of age-related osteoporosis: impaired mechano-responsiveness of bone is not the culprit. PLoS One 3(7):e2540 (10 pages)

Liu C, Zhao Y, Cheung W-Y, Gandhi R, Wang L, You L (2010) Effects of cyclic hydraulic pressure on osteocytes. Bone 46(5):1449-1456

Liu J, Zhao Z, Li J, Zou L, Shuler C, Zou Y, Huang X, Li M, Wang J (2009) Hydrostatic pressures promote initial osteodifferentiation with ERK 1/2 not p38 signalling involved. J Cell Biochem 107(2):224-232

Marino A, Becker R (1970) Piezoelectric effect and growth control in bone. Nature 228(5270):473-474

Marino A, Becker R, Soderholm S (1971) Origin of the piezoelectric effect in bone. Calcif Tissue Int 8(1):177-180

Martin R, Burr D, Sharkey N (1998) Skeletal tissue mechanics. Springer, Berlin 
Maul T, Hamilton D, Nieponice A, Soletti L, Vorp D (2007) A new experimental system for the extended application of cyclic hydrostatic pressure to cell culture. J Biomech Eng 129(1):110-116

McCarthy R, Jeffcott L, McCarthey R (1990) Ultrasound speed in equine cortical bone: Effects of orientation, density, porosity and temperature. J Biomech 23(11):1139-1143

Mehrabian A, Abousleiman Y (2011) General solutions to poroviscoelastic model of hydrocephalic human brain tissue. J Theor Biol 291:105-118

Mikić B, Carter D (1995) Bone strain gage data and theoretical models of functional adaptation. J Biomech 28(4):465-469

Morin C, Hellmich C (2013) Mineralization-driven bone tissue evolution follows from fluid-to-solid phase transformations in closed thermodynamic systems. J Theor Biol 335:185-197

Morin C, Hellmich C (2014) A multiscale poromicromechanical approach to wave propagation and attenuation in bone. Ultrasound 54(5):1251-1269

Morin C, Hellmich C, Henits P (2013) Fibrillar structure and elasticity of hydrating collagen: a quantitative multiscale approach. J Theor Biol 317:384-393

Murdock J (1996) Mark's standard handbook for mechanical engineers, chapter mechanics of fluids, 10th edition, pp 3.29-3.61. McGrawHill

Nagatomi J, Arulanandam B, Metzger D, Meunier A, Bizios R (2001) Frequency- and duration dependent effects of cyclic pressure on select bone cell functions. Tissue Eng 7(6):717-730

Nagatomi J, Arulanandam B, Metzger D, Meunier A, Bizios R (2002) Effects of cyclic pressure on bone marrow cell cultures. J Biomech Eng 124:308-314

Nagatomi J, Arulanandam B, Metzger D, Meunier A, Bizios R (2003) Cyclic pressure affects osteoblast functions pertinent to osteogenesis. Ann Biomed Eng 31(8):917-923

Nguyen V-H, Lemaire T, Naili S (2010) Poroelastic behaviour of cortical bone under harmonic axial loading: a finite element study at the osteonal scale. Med Eng Phys 32(4):384-390

Nikoyaan A, Veeger H, Westerhoff P, Graichen F, Bergmann G, van der Helm F (2009) How well does a musculoskeletal model predict GH-joint contact forces? Comparison with in vivo data. In: Proceedings of the ASME 2009 international design engineering technical conferences and computers and information in engineering conference (IDETC/CIE 2009), volume 4 of ASME proceedings, pp 1575-1581. The American Society of Mechanical Engineers

Onal M, Piemontese M, Xiong J, Wang Y, Han L, Ye S, Komatsu M, Selig M, Weinstein R, Zhao H, Jilka R, Almeida M, Manolagas S, O'Brien C (2013) Suppression of autophagy in osteocytes mimics skeletal aging. J Biol Chem 288(24):17432-17440

Ozawa H, Imamura K, Abe E, Takahashi N, Hiraide T, Shibasaki Y, Fukuhura T, Suda T (1990) Effect of a continuously applied compressive pressure on mouse osteoblast-like cells (MC3T3-E1) in vitro. J Cell Physiol 142(1):177-185

Padilla F, Jenson F, Bousson V, Peyrin F, Laugier P (2008) Relationships of trabecular bone structure with quantitative ultrasound parameters: in vitro study on human proximal femur using transmission and backscatter measurements. Bone 42(6):1193-1202

Pajevic P (2009) Regulation of bone resorption and mineral homeostasis by osteocytes. IBMS BoneKey 6(2):63-70

Pearson O, Lieberman D (2004) The aging of Wolff's "law": ontogeny and responses to mechanical loading in cortical bone. Am J Phys Anthropol 125(Suppl. 39):63-99

Pichler B, Hellmich C (2010) Estimation of influence tensors for eigenstressed multiphase elastic media with nonaligned inclusion phases of arbitrary ellipsoidal shape. J Eng Mech 136(8):1043-1053

Pienkowski D, Pollack S (1983) The origin of stress-generated potentials in fluid-saturated bone. J Orthop Res 1(1):30-41
Pivonka P, Hellmich C, Smith D (2004) Microscopic effects on chloride diffusivity of cement pastes-a scale-transition analysis. Cem Concr Res 34(12):2251-2260

Pollack G (2001) Cells, gels, and the engines of life. Ebner and Sons, Seattle

Pollack G (2013) The fourth phase of water beyond solid, liquid, and vapor. Ebner and Sons, Seattle

Pollack G, Clegg J (2008) Phase transitions in cell biology, chapter unexpected linkages between unstirred layers, exclusion zones, and water. Springer, Netherlands, pp 143-152

Pollack S, Petrov N, Salzstein R, Brankov G, Blagoeva R (1984) An anatomical model for streaming potentials in osteons. J Biomech 17(8):627-636

Price C, Zhou X, Li W, Wang L (2011) Real-time measurement of solute transport within the lacunar-canalicular system of mechanically loaded bone: Direct evidence for load-induced fluid flow. J Bone Miner Res 26(2):277-285

Qin Y-X, Kaplan T, Saldanha A, Rubin C (2003) Fluid pressure gradients, arising from oscillations in intramedullary pressure, is correlated with the formation of bone and inhibition of intracortical porosity. J Biomech 36:1427-1437

Qin Y-X, Lin W, Rubin C (2002) The pathway of bone fluid flow as defined by in vivo intramedullary pressure and streaming potential measurements. Ann Biomed Eng 30(5):693-702

Reilly G, Knapp H, Stemmer A, Niederer P, Knothe Tate M (2001) Investigation of the morphology of the lacunocanalicular system of cortical bone using atomic force microscopy. Ann Biomed Eng 29(12):1074-1081

Reinish G, Nowick A (1975) Piezoelectric properties of bone as functions of moisture content. Nature 253(5493):626-627

Roelofsen J, Klein-Nulend J, Burger E (1995) Mechanical stimulation by intermittent hydrostatic compression promotes bone-specific gene expression in vitro. J Biomech 28(12):1493-1503

Rohlmann A, Zander T, Graichen F, Schmidt H, Bergmann G (2014) How does the way a weight is carried affect spinal loads? Ergonomics 57(2):262-270

Rottmar M, Ackerknecht S, Wick P, Maninuar-Weber K (2011) A high throughput system for long-term application of intermittent cyclic hydrostatic pressure on cells in culture. J Biomech Eng 133(024502):1-5

Rubin J, Biskobing D, Fan X, Rubin C, McLeod K, Taylor W (1997) Pressure regulates osteoclast formation and MCSF expression in marrow culture. J Cell Physiol 170:81-87

Salençon J (2001) Handbook of continuum mechanics. Springer, Berlin

Santos A, Bakker A, Klein-Nulend J (2009) The role of osteocytes in bone mechanotransduction. Osteoporos Int 20(6):1027-1031

Sasaki N, Tagami A, Goto T, Taniguchi M, Nakata M, Hikichi K (2002) Atomic force microscopic studies on the structure of bovine femoral cortical bone at the collagen fibril-mineral level. J Mater Sci Mater Med 13(3):333-337

Scheiner S, Pivonka P, Hellmich C (2013) Coupling systems biology with multiscale mechanics, for computer simulations of bone remodeling. Comput Methods Appl Mech Eng 254:181-196

Scheiner S, Pivonka P, Smith D, Dunstan C, Hellmich C (2014) Mathematical modeling of postmenopausal osteoporosis and its treatment by the anti-catabolic drug denosumab. Int J Numer Methods Biomed Eng 30(1):1-27

Seliger W (1970) Tissue fluid movement in compact bone. Anat Rec 166(2):247-255

Sharma D, Ciani C, Ramirez Marin P, Levy J, Doty S, Fritton S (2012) Alterations in the osteocyte lacunar-canalicular microenvironment due to estrogen deficiency. Bone 51(3):488-497

Sinclair C, Birch H, Smith R, Goodship A (2013) Equine sports medicine and surgery, chapter Skeletal physiology: responses to exercise and training, 2nd edition, pp 145-165. Saunders Ltd 
Smit T, Huyghe J, Cowin S (2002) Estimation of the poroelastic parameters of cortical bone. J Biomech 35(6):829-835

Suquet P (1997) Continuum micromechanics, volume 377 of CISM courses and lectures. Springer, New York

Tai K, Pelled G, Sheyn D, Bershteyn A, Han L, Kallai I, Zilberman Y, Ortiz C, Gazit D (2008) Nanobiomechanics of repair bone regenerated by genetically modified mesenchymal stem cells. Tissue Eng Part A 14(10):1709-1720

Takai E, Mauck R, Hung C, Guo X (2004) Osteocyte viability and regulation of osteoblast function in a 3D trabecular bone explant under dynamic hydrostatic pressure. J Bone Miner Res 19(9):1403-1410

Thompson D (1936) On growth and form. Cambridge University Press, Cambridge

Thompson W, Modla S, Grindel B, Czymmek K, Kirn-Safran C, Wang L, Duncan R, Farach-Carson M (2011) Perlecan/Hspg2 deficiency alters the pericellular space of the lacunocanalicular system surrounding osteocytic processes in cortical bone. J Bone Miner Res 26(3):618-629

Thomsen J, Ebbesen E, Mosekilde L (2002) Age-related differences between thinning of horizontal and vertical trabeculae in human lumbar bone as assessed by a new computerized method. Bone 31(1):136-142

Turner C, Pavalko F (1998) Mechanotransduction and functional response of the skeleton to physical stress: the mechanisms and mechanics of bone adaptation. J Orthop Sci 3(6):346-355

Turner C, Takano Y, Owan I (1995) Aging changes mechanical loading thresholds for bone formation in rats. $\mathrm{J}$ Bone Miner Res 10(10): 1544-1549

Vergne L, Meunier A, Adolphe M, Sedel L (1996) A new apparatus for studying the effect of hydrostatic pressure on cells in culture. Cytotechnology 21(1):21-30

von Terzaghi K (1923) Die Berechnung der Durchlässigkeitsziffer des Tones aus dem Verlauf der hydrodynamischen Spannungserscheinungen [Calculation of the permeability number of clay based on the development of hydrodynamic stresses]. Sitzungsberichte der Mathematisch-Naturwissenschaftlichen Classe, Abteilung IIa, der Kaiserlichen Akademie der Wissenschaften 132(3/4):125-138

Vuong J, Hellmich C (2011) Bone fibrillogenesis and mineralization: quantitative analysis and implications for tissue elasticity. J Theor Biol 287:115-130
Wang B, Zhou X, Price C, Li W, Pan J, Wang L (2014) Quantifying load-induced solute transport and solute-matrix interaction within the osteocyte lacunar-canalicular system. J Bone Miner Res 28(5):1075-1086

Wang L, Wang Y, Han Y, Henderson S, Majeska R, Weinbaum S, Schaffler M (2005) In situ measurement of solute transport in the bone lacunar-canalicular system. Proc Natl Acad Sci USA 102(33):11911-11916

Weinbaum S, Cowin S, Zeng Y (1994) A model for the excitation of osteocytes by mechanical loading-induced bone fluid shear stresses. J Biomech 27(3):339-360

Wilson F, Dietschy J (1974) The intestinal unstirred layer: its surface area and effect on active transport kinetics. Biochim at Biophys Acta 363(1):112-126

Yosibash Z, Trabelsi N, Hellmich C (2008) Subject-specific p-FE analysis of the proximal femur utilizing micromechanics-based material properties. Int J Multiscale Comput Eng 6(5):483-498

You L-D, Weinbaum S, Cowin S, Schaffler M (2004) Ultrastructure of the osteocyte process and its pericellular matrix. Anat Rec 278A(2):505-513

Zaoui A (1997) Structural morphology and constitutive behavior of microheterogeneous materials, chapter 6, pp 291-347. Springer, New York. In Suquet (1997)

Zaoui A (2002) Continuum micromechanics: survey. J Eng Mech 128(8):808-816

Zeng Y, Cowin S, Weinbaum S (1994) A fiber matrix model for fluid flow and streaming potentials in the canaliculi of an osteon. Ann Biomed Eng 22(3):280-292

Zhang Y, Gandhi A, Zeglinski J, Gregor M, Tofail S (2012) A complementary contribution to piezoelectricity from bone constituents. IEEE Trans Dielectr Electr Insul 19(4):1151-1157

Zhou X, Novotny J, Wang L (2008) Modeling fluorescence recovery after photobleaching in loaded bone: potential applications in measuring fluid and solute transport in the osteocytic lacunarcanalicular system. Ann Biomed Eng 36(12):1961-1977 